\title{
MEASURING LAW STUDENTS' ATTITUDES TOWARDS AND EXPERIENCES OF CLINICAL LEGAL EDUCATION AT THE UNIVERSITY OF HONG KONG
}

Claudia Man-yiu Tam, The University of Hong Kong ${ }^{1}$

\begin{abstract}
As law schools in Hong Kong begin to integrate experiential learning into their educational models, clinical legal education (CLE) has symbiotically gained traction as an effective way for students to apply their legal knowledge in a skills-based and clientcentered environment. This empirical study is the first of its kind to evaluate the impacts of CLE at The University of Hong Kong (HKU) over the past ten years, by analyzing the survey responses provided by 125 law students regarding their attitudes towards and experiences of CLE. The article traces the birth and development of CLE at HKU, turning first to its theoretical basis to make the case for its importance, and placing emphasis on the ability of CLE's teaching-service pedagogy to alleviate the public interest law deficit and supplement passive learning as an engaging instructional method in the Hong Kong context. The survey results are then discussed in light of the doctrinal analysis to illustrate that clinic and non-clinic students alike are generally satisfied that HKU's CLE program
\end{abstract}

\footnotetext{
${ }^{1}$ Claudia Man-yiu Tam is from The University of Hong Kong
} 
has achieved its skills, cognitive, and civic aims, and notably, that clinic students had a statistically significant higher intention to participate in pro bono work after graduation than non-clinic students or students engaged in volunteering.

Keywords: Clinical legal education; experiential learning; pro bono; teaching-service pedagogy

\section{INTRODUCTION}

Since its proliferation in response to the early 20th century legal aid access to justice movement in the United States (US) ${ }^{2}$, clinical legal education (CLE) has been lauded as a transformative experiential learning model, bridging the gap between teaching law students black letter law and professional skills and advancing law clinicians' social justice and service mission. ${ }^{3}$ The successful introduction of CLE at The University of

\footnotetext{
2 Bloch, S.F. (ed), The Global Clinical Movement: Educating Lawyers for Social Justice (OUP 2011), pp.156-158;

Wilson, J.R. The Global Evolution of Clinical Legal Education: More than a Method (CUP 2017), pp.93-94;

Robert Granfield, R. 'Institutionalizing Public Service in Law School: Results on the Impact of Mandatory Pro Bono Programs'. (2007). 54 Buffalo Law Review 1355, 1364-1373; Spiegel, M. 'Theory and Practice in Legal Education: An Essay on Clinical Education'. (1987). 34 UCLA Law Review 577, 577-595.

${ }^{3}$ Shanahan, F.C., Selbin, J. \& Mark, A. et al., 'Measuring Law School Clinics'. (2018). 92 Tulane Law Review 547, 550; Evans, A., Cody, A. \& Copeland, A. et al., Australian clinical legal education: Designing and operating a best practice clinical program in an Australian law school .(2017). ANU Press, pp.40-76; Rhode, L.D 'Cultures of Commitment: Pro Bono for Lawyers and Law Students' (1999) 67 Fordham Law Review 2415, 2435.
} 
Hong Kong (HKU) in $2009^{4}$ was a testament to its international reach and pedagogical value. While there is a rich body of literature on its purported objectives and benefits, empirical research capturing law students' perspectives on CLE is sparse ${ }^{5}$, particularly in the Hong Kong context with few, if any, prior publications on this subject. In a modest attempt to begin to fill this knowledge gap and identify areas for further research, this quantitative study, which drew heavily on McKeown's survey ${ }^{6}$, sought to measure law students' attitudes towards and experiences of CLE, volunteering, and pro bono work at HKU. Two main research questions were formulated as follows: “What are law students' attitudes towards CLE and pro bono work? Are there differences in these attitudes when comparing students who have undertaken or are undertaking CLE (clinic students) and students who have not taken CLE (non-clinic students)?". To this end, an online survey ${ }^{7}$ was administered to 809 first- to fifth-year HKU undergraduate law students enrolled in three compulsory law courses, of which there were 125 respondents in total.

The data suggested that both clinic and non-clinic students' attitudes towards CLE at HKU are positive. The vast majority of students agreed with statements saying that their

\footnotetext{
4 ‘HKU-HKRAC Clinical Legal Education Programme' (Human Rights Portal)

$<$ http://www.law.hku.hk/hrportal/asylum/hku-hkrac-clinical-legal-education-programme> accessed 24.03.2019 (HKU-HKRAC).

${ }^{5}$ Shanahan (n.3).

${ }^{6}$ McKeown, P. 'Law student attitudes towards pro bono and voluntary work: The experience at Northumbria University'. (2015). 22 International Journal of Clinical Legal Education 6.

7 See Appendix A.
} 
CLE experience improved their legal skills and increased their awareness and changed their perception of social and economic issues. They also agreed that CLE encouraged them to participate in pro bono work after graduation and played an important role in supporting the wider community. The findings were particularly evident among clinic students. A comparison between the mean attitudes of clinic and non-clinic students using a two-sample unequal variance (independent) t-test revealed a statistically significant higher level of agreement towards these statements. The analysis also indicated that clinic students had a statistically significant higher intention to engage in pro bono work after graduation than non-clinic students. Moreover, using the Pearson product-moment correlation coefficient, there was a stronger positive correlation between clinic students and their intention to do pro bono work, as compared to students who had participated or were participating in volunteering (student volunteers). The study therefore suggested that, in general, CLE is viewed positively by HKU law students and especially among clinic students. Clinic students are more amenable to pro bono work, in comparison to their non-clinic and student volunteer counterparts, although this is not indicative of a causal relationship between CLE and pro bono work. 


\section{THEORETICAL FRAMEWORK}

\section{Defining Clinical Legal Education}

Clinical legal education (CLE) is a form of experiential learning which requires law students to solve complex, concrete, and unrefined 'problems that lawyers might confront in practice' in role. ${ }^{8}$ CLE serves clients who are typically from 'disadvantaged, underserved, or marginal' community groups and are unable to access justice, whether due to financial constraints, lack of accessibility, or education or language barriers. ${ }^{9} \mathrm{Clinic}$ students are given 'ownership of the case', as they bear the sole responsibility of understanding and analyzing their client's problems, formulating possible solutions, and planning and executing suitable courses of action. ${ }^{10}$ The experiential component of CLE is usually accompanied by a classroom component. Integrated lessons are delivered by clinical faculty to facilitate and contextualize the students' practical learning experience. These lessons may cover substantive legal theories and doctrines, professional ethics and values, and lawyering skills. ${ }^{11}$ CLE includes a central element of self-reflection and critical

\footnotetext{
8 Amsterdam, G.A. 'Clinical Legal Education - A 21st Century Perspective'. (1984). 34 Journal of Legal Education 612, 616; Caplow, S. 'Clinical Legal Education in Hong Kong: A Time to Move Forward'. (2006). 36 Hong Kong Law Journal 229,230.

${ }^{9}$ Wilson, J.R ‘Training for Justice: The Global Reach of Clinical Legal Education'. (2004). 22 Penn State International Law Review 421, 423.

${ }^{10}$ Amsterdam (n.8) 616; Caplow (n.8) 233; Redlich, N. 'Moral Value of Clinical Legal Education: A Reply'. (1983). 33 The Journal of Legal Education 613, 616.

${ }_{11}$ Wilson, Global Evolution of Clinical Legal Education (n.2), pp.423; Evans, Cody, Copeland et al (n 3), pp.110.
} 
review - for instance through directed questions, reflective discussions, or reflective essays - such that each student's individual thoughts and behavior within and outside the clinic becomes the central focus of their own study. ${ }^{12}$ This reflective practice is the "minimum standard" required of CLE, in order to "[help] students learn how to learn from experience" and actively reevaluate their preconceived notions of the role of law and lawyers in empowering members of society. ${ }^{13}$

The basic models of CLE are in-house live-client clinics, externships, simulations, and community legal education or street law. ${ }^{14}$ An in-house live-client clinic is based in a law office, normally located on the university campus. It provides students with the chance to handle legal matters on behalf of real clients. In some jurisdictions, law students in clinics can directly represent clients in court, negotiate with opposing counsel, and write opinion letters providing substantive legal advice to their clients. ${ }^{15}$ However, because regulations prohibit law students in Hong Kong from doing so, their work revolves around other important tasks aiding access to justice, such as taking instructions from clients, preparing case summaries and research memorandums, and assisting legal aid lawyers in delivering legal advice to clients.

\footnotetext{
${ }^{12}$ Amsterdam (n.8), pp.616-617.

${ }^{13}$ Evans, Cody, Copeland et al. (n.3), pp.153-160.

${ }^{14}$ Milstein, E.S 'Clinical Legal Education in the United States: In-House Clinics, Externships, and Simulations' (2001) 51 Journal of Legal Education 375, 376.

${ }^{15}$ Ibid, (2001).
} 
In an externship, students are assigned to external law offices either within government agencies, non-governmental organizations (NGOs), or private law firms to work on their cases, primarily under the supervision of their staff. As part of the classroom component to supplement live-client clinics and externships or as a standalone course, simulations place law students into simulated lawyer roles through conducting role plays. Students are given a hypothetical situation that may be modeled on a real-world legal problem and are asked to react as a lawyer would. Another model often included within CLE is street law ${ }^{16}$, which gives law students the opportunity to teach a segment of the community about their legal rights using interactive pedagogical methods. ${ }^{17}$ Which of these four models is ultimately adopted may depend on cost, resources, timing, restrictions on student practice, and staffing. ${ }^{18}$

\footnotetext{
${ }^{16}$ Wilson, Global Evolution of Clinical Legal Education (n.2), pp.423.

${ }_{17}$ Barry, M.M., Camp, R.A., Johnson, E.M., et al. 'Teaching Social Justice Lawyering: Systematically Including Community Legal Education in Law School Clinics'. (2012). 18 Clinical Law Review 401, 404-407. ${ }^{18}$ Wizner, S. \& Curtis, D. 'Here's What We Do: Some Notes about Clinical Legal Education'. (1980). 29 Cleveland State Law Review 673, 681; Grossman, S.G. 'Clinical Legal Education: History and Diagnosis'. (1973). 26 Journal of Legal Education 162, 182-184; Rhode (n.3), pp.2443.
} 


\section{FROM VISION TO REALITY: BIRTH AND GROWTH OF CLINICAL LEGAL} EDUCATION IN HONG KONG

The concept of CLE was ushered into Hong Kong in 2001, as a result of the publication of the Report on Legal Education and Training in Hong Kong: Preliminary Review (Redmond-Roper Report). ${ }^{19}$ The Law Society of Hong Kong commissioned the RedmondRoper Report to evaluate the strengths and weaknesses of legal pedagogy at universities and to provide recommendations on how to better equip law students for legal practice. The Report found that the prevailing form of teaching was composed of lectures and tutorials, which troublingly rarely involved active student participation..$^{20}$ It also observed a public interest law deficit, as Hong Kong's legal profession lacked a culture of volunteerism and pro bono work, which in turn exacerbated the societal problem of providing insufficient legal assistance to citizens. ${ }^{21}$ Despite the majority of students entering law school with altruistic ideals of promoting social justice through their future legal practice, only the few who maintained contact with a "public interest subculture" throughout their studies - either through public interest internships or pre-existing community service engagements - kept that commitment. ${ }^{22}$

\footnotetext{
${ }^{19}$ The Steering Committee on the Review of Legal Education and Training in Hong Kong, Report on Legal Education and Training in Hong Kong: Preliminary Review (The Law Society of Hong Kong 2001) <http://www.hklawsoc.org.hk/pub_e/news/societyupdates/20010813a.asp> accessed 24.03.2019 (Redmond-Roper Report); Wilson, Global Evolution of Clinical Legal Education (n 2), pp.250.

${ }^{20}$ Wilson, (n.3) (2004). para 7.6.2.

${ }^{21} \mathrm{Ibid},(2004)$. para 14.1.2.

22 Ibid, (2004). para 14.3.3.
} 
In response to these problems, the Report recommended for law schools to integrate CLE into its curriculum. CLE could cultivate students' commitment to public service and pro bono work, expose them to "the legal problems of the poor" 23 and the realities of professional practice, and facilitate their understanding of the human impact of law beyond the four classroom walls. ${ }^{24}$ Notably, the Report suggested that the three Hong Kong law schools - HKU, The Chinese University of Hong Kong (CUHK), and City University of Hong Kong - could operate a joint legal clinic. ${ }^{25}$ If this was not possible, these law schools could create externships, supervised by external agencies engaged in legal service provision, supplemented with accompanying seminars to support students' reflection and development of lawyering skills. ${ }^{26}$

The capacity of HKU to instigate CLE as suggested by the Redmond-Roper Report was further considered by Caplow, who concluded in her seminal work that the "basic requisites" for CLE were present in Hong Kong. ${ }^{27}$ She explicated the potential of CLE to meet Hong Kong citizens' unmet legal needs, for instance, by providing assistance to the "sandwich class" who are not caught by the net of legal aid or to litigants in person who,

\footnotetext{
${ }^{23}$ Ibid, (2004). para 7.6.6.

${ }^{24}$ Ibid, (2004).

${ }^{25}$ Ibid, (2004), pp.355.

${ }^{26}$ Wilson, (n.3) (2004), pp.364.

${ }_{27}$ Caplow, (n.8) (2006), pp.258.
} 
for whatever reason, are refused legal aid. ${ }^{28}$ Seeing few existing CLE opportunities at $\mathrm{HKU}^{29}$, she proposed a range of possible directions for CLE to develop. She suggested establishing a live-client clinic, where students would provide one-off legal advice to clients, or offering law firm or NGO externships, where students would work alongside pro bono lawyers on legal problems or execute policy and research projects. She also proposed running street law programs to communicate legal ideas to community groups and adding simulations to inject life into curriculums. ${ }^{30}$

The Report and Caplow's CLE vision materialized in January 2009, when HKU's Center for Comparative and Public Law (CCPL), in conjunction with the Hong Kong Refugee Advice Center (HKRAC), pioneered the first credit-bearing elective CLE program in Hong Kong. ${ }^{31}$ The HKU-HKRAC CLE Program (Refugee Clinic) familiarized HKU students with the theory and practice of refugee law in an experiential learning environment. Following a two-day intensive training weekend, students worked under the direct supervision of HKRAC's staff to first observe and then perform client registration and intake interviews, write client testimony and legal briefs, and conduct country of origin information research. Due to the special nature of the United Nations

\footnotetext{
${ }^{28} \mathrm{Ibid},(2006)$, pp.245-246.

${ }^{29}$ Ibid, (2006), pp.239.

30 Ibid, (2006), pp. 246.

${ }^{31}$ HKU-HKRAC (n.4).
} 
High Commissioner for Refugees (UNHCR) process, students took ownership over client cases and directly practiced international law. Through exposing HKU students to ethical dilemmas, the Refugee Clinic aimed to encourage them to evaluate a legal practitioner's professional and ethical responsibilities in a practical setting, reflect on the power and knowledge asymmetry and trust involved in a lawyer-client relationship, and serve the community while developing interviewing, advocacy, negotiation, investigation, and legal research and writing skills. Students also attended weekly seminars, where they discussed the casework with their supervisor and did theoretical and practical exercises to consolidate their understanding.

This Clinic was followed shortly in 2010 by the initiation of HKU's live-client CLE Program, which remains as part of the Hong Kong Duty Lawyer Service Free Legal Advice Scheme (FLAS). ${ }^{32}$ By conducting intake interviews and assisting lawyers in providing preliminary legal advice to clients, FLAS allows students to contextualize their textbook knowledge in real-world cases and understand the significant impact a conscientious and client-centered lawyer can make on a client's experience with the legal

\footnotetext{
32 'HKU's Live-Client Clinical Legal Education ("CLE”) Programme' (Hong Kong Lawyer, November 2015) $<$ http://www.hk-lawyer.org/content/hku's-live-client-clinical-legal-education-"cle"-programme> accessed 24.03.2019; 'Free Legal Advice Scheme on HKU Campus' (Free Legal Advice Scheme on HKU Campus, Faculty of Law, The University of Hong Kong) <http://www.law.hku.hk/cle/> accessed 24.03.2019.
} 
system, while filling the service gaps in the Hong Kong community. ${ }^{33}$ The classroom component consists of weekly meetings where students meet with clinical faculty to debrief their casework. To facilitate reflection, students are required to keep up to date their reflection portfolios. ${ }^{34}$ Similarly, HKRAC provided an external clinic for CUHK in 2009, which was later moved internally as the Clinic for Public Interest Advocacy in $2014 . .^{35}$

Subsequently, CLE at HKU proliferated. Three new CLE elective courses were introduced in addition to the existing Refugee Clinic and FLAS, namely Human Rights in Practice in 2015, followed by Global Migration Legal Clinic in 2018, and most recently in 2019, Disability Rights Clinic. Human Rights in Practice engages HKU students in street law under the supervision of clinical faculty and pro bono lawyers, with students planning, testing, and delivering at least three teaching sessions in collaboration with community partners. Students are supported by extensive pedagogical training and opportunities for self-reflection during weekly seminars. ${ }^{36}$ In Global Migration Legal

\footnotetext{
${ }_{33}$ 'Scheme Poster (January 2019 semester)' (Free Legal Advice Scheme on HKU Campus, Faculty of Law, The University of Hong Kong) <https://www.law.hku.hk/cle/?page_id=23> accessed 24.03.2019.

34 ‘LLAW3148 Clinical Legal Education' <https://www.law.hku.hk/course/llaw3148-clinical-legaleducation/> accessed 25.03.2019.

${ }^{35}$ Marsh, L. \& Ramsden, M. 'Fostering Civic Engagement in Legal Education: Observations from Hong Kong'. (2014). 1 Asian Journal of Legal Education 1; Marsh, L. \& Ramsden, M. 'Developments in Hong Kong Legal Education'. (2016). 3 Asian Journal of Legal Education 2.

36 'LLAW3222 Human Rights in Practice' <https://www.law.hku.hk/course/llaw3222-human-rights-inpractice/> accessed 24.03.2019.
} 
Clinic, students work with fieldworkers and NGOs to brainstorm and implement holistic and innovative solutions to ameliorate specific labor problems faced by migrant domestic workers in Hong Kong. ${ }^{37}$ Disability Rights Clinic partner with disability rights groups to give students experiential learning opportunities, such as drafting legal documents, developing client care techniques, and implementing community legal education curricula, alongside weekly seminars on substantive disability rights and theory. ${ }^{38}$ These courses all have elements of self-reflection.

\section{Why Clinical Legal Education Matters}

The value of CLE lies in its seamless integration of a dualistic teaching-service model, which bridges the gap between legal knowledge and practice ${ }^{39}$, while simultaneously transforming law schools into "centers of social justice". ${ }^{40}$ Turning first to its teaching model, CLE is crucial for skills-based learning, because it alleviates the shortcomings of legal education in training students for legal practice. While the Socratic method adopted by most law schools teach law students analytical reasoning or how to "[think] like a lawyer" (cognitive dimension), it fails to teach students the skills required to act like a lawyer, including performing basic practical tasks (skills dimension) and conducting

\footnotetext{
37 'LLAW3252 The Global Migration Legal Clinic' <https://www.law.hku.hk/course/llaw3252-the-globalmigration-legal-clinic/> accessed 24.03.2019.

38 'LLAW3246 Disability rights clinic' <https://www.law.hku.hk/course/llaw3246-disability-rights-clinic/> accessed 24.03.2019.

${ }^{39}$ Rhode (n.3).

${ }^{40}$ Ashar, S. 'Law Clinics and Collective Mobilization'. (2008) 14 Clinical Law Review 355, pp.357.
} 
themselves with professional, moral, and ethical responsibility (civic dimension). ${ }^{41}$ The Carnegie Report, a report conducted in the US akin to the Redmond-Roper Report, refers to these dimensions as "three aspects of legal apprenticeship" in legal education. ${ }^{42}$ Particularly in Hong Kong, apart from the problem of passive rote learning, the division between the academic stage of learning (a four-year Bachelor of Laws degree), followed by the vocational stage (a one-year Postgraduate Certificate in Laws) created a legal education system that "[lacked] theoretical coherences, clear direction, and [relevant] material". ${ }^{43}$

As a solution, CLE effectively amalgamates these three cognitive, skills, and civic dimensions into its symbiotic teaching model. The skills learned by doing include client interviewing and counseling, fact gathering and sifting, legal research and drafting, decision-making on alternative strategies, negotiation, and advocacy. ${ }^{44}$ Critics of skills training argue that law schools should only be performing "intelligence functions" and teaching students the "how to of thinking", while others point out that students may pursue alternative careers besides law. ${ }^{45}$ However, these arguments misinterpret CLE as

\footnotetext{
${ }^{41}$ Sandefur, R. \& Selbin, J. ‘The Clinic Effect'. (2009). 16 Clinical Law Review 57, pp.61.

${ }^{42}$ Sullivan, W.M, Colby, A. \& Welch, J. et al. Educating Lawyers: Preparation for the Profession of Law. (2007). Jossey-Bass, pp.191.

${ }^{43}$ Redmond-Roper Report (n.19) para 7.4.6.

${ }^{44}$ Grossman, (1973) (n.18), pp.187-188.

${ }^{45}$ Ibid, (1973) pp.189-191.
} 
purely being a legal skills training exercise. In fact, skills development is the critical foundation of self-directed theoretical insight and interdisciplinary study ${ }^{46}$ The crux of CLE is to prompt students' "intellectual penetration of the processes in which practical skills are but surface manifestations" ${ }^{47}$, thereby deepening their cognitive understanding of society as a whole. For example, client interactions can provoke a student's critical thinking of the impact of a client's background and current situation on their reaction to the law and official discretion ${ }^{48}$ and how this might play into pre-existing biases or generate misunderstanding. This may subsequently encourage the student to embark on deeper normative reasoning about what the law should be, as opposed to what it currently is.

These cognitive processes are supported by the classroom component, which not only acquaints students with black letter substantive law and the wider socio-economic context, but also feeds back into the skills development to prompt lines of thought about the "lawyering process" and the "problems of role, personal interaction, purpose, perception, and communication" raised. ${ }^{49}$ CLE also serves a wider civic and academic function within the university, as it changes conversations between students to include

\footnotetext{
${ }^{46}$ Ibid, (1973), pp.192.

${ }^{47}$ Ibid, (1973)

${ }^{48}$ Ibid, (1973)

${ }^{49}$ Bellow, G. \& Johnson, E. 'Reflections on the University of Southern California Clinical Semester'. (1971). 44 Southern California Law Review 664, pp.673.
} 
social issues through sharing their service experiences with others. ${ }^{50}$ The thinking processes practiced - testing hypotheses, making generalizations, reflection, and selfcritique - are transferable across most, if not all, occupations, so CLE is still relevant for students seeking alternative careers.

Concurrently, the service model "humanizes the educational process" 51 and exposes students to the human impact of law, which is especially needed in Hong Kong where the volunteering and pro bono culture is lacking. ${ }^{52}$ CLE is often a student's first exposure to people from different social and economic demographics ${ }^{53}$, which may raise fresh queries for them about the intersectionality of systemic legal and social problems and how this impacts access to justice. For example, in teaching street law to people with intellectual differences for the first time, a student may reflect on entrenched discriminatory attitudes and practices which cause a systematic exclusion of people with disabilities from society, and how this in turn, may obstruct their access to justice and other human rights. In providing individualized legal services to disadvantaged client groups, students add to their learning experience "a feeling for humanity and decency" 54,

\footnotetext{
${ }^{50}$ Lesnick, H. 'Why Pro Bono in Law Schools'. (1994). 13 Law \& Inequality: A Journal of Theory and Practice 25, pp.37.

${ }^{51}$ Pincus, W. 'The Clinical Component in University Professional Education'. (1971). 32 Ohio State Law Journal 283, pp.286.

${ }^{52}$ Redmond-Roper Report (n.19) para 14.1.2.

53 Wilson, Global Evolution of Clinical Legal Education (n 2), pp.423.

${ }^{54}$ Caplow (n.8) 246; Redlich (n.10), pp.617-618.
} 
discover the dire need for pro bono work, and explore their own potential to be an "empowering force in the lives of poor clients" 55 , all of which may inculcate in them an interest in pro bono work or a public interest career. Not only does this improve the societal distribution of justice, it also influences students to reject the neutrality of the law and adopt the role of a community lawyer that interacts collaboratively with community members in a multi-faceted manner. ${ }^{56}$ On a wider scale within the university, CLE can serve as "symbols and models of justice in action", encouraging law schools to claim ownership over educating students on their responsibility to ameliorate injustices. ${ }^{57}$

\section{MEASURING THE CLINIC EFFECT}

Despite extensive literature on the aims and theories of CLE, sparse empirical research has been done on the attitudes and experiences of students towards CLE. ${ }^{58}$ Of the limited studies conducted, McKeown's work concluded that although clinic students at Northumbria University believed that their legal skills, awareness of social and economic issues, and employability improved, their CLE experience was primarily motivated by

\footnotetext{
${ }^{55}$ Barry, Camp, Johnson et al. (n.17), pp.408.

${ }^{56}$ Barnhizer, D. 'The University Ideal and Clinical Legal Education'. (1990). 35 New York Law School Law Review 87, pp.106-113; Evans, Cody, Copeland et al. (n.3), pp.111-116; Seielstad, A.M. ‘Community Building as a Means of Teaching Creative, Cooperative, and Complex Problem Solving in Clinical Legal Education'. (2002). 8 Clinical Law Review 445, pp.451-456.

${ }^{57}$ Seielstad (n.56)

${ }^{58}$ Krieger, S.H. 'The Effect of Clinical Education on Law Student Reasoning: An Empirical Study'. (2008). 35 William Mitchell Law Review 359, 362.
} 
personal benefit and did not translate into a desire to undertake pro bono work following graduation. ${ }^{59}$ Adewumi and Bamgbose's work at the University of Ibadan showed that student attitudes towards CLE were very positive, with $91.9 \%$ of students preferring it to lectures, $90.3 \%$ attesting that CLE prepared them for real-life cases and created a culture of identifying with less privileged people, and $88.7 \%$ agreeing that CLE helped them to acquire more knowledge. ${ }^{60}$ However, their work did not investigate whether CLE led to increased participation in pro bono work, nor did they study student motivations for doing CLE. In a slightly different vein, other empirical studies have considered whether clinic students' problem-solving and reasoning ${ }^{61}$ and client representation skills ${ }^{62}$ have improved, by for example, comparing student responses to hypothetical situations with lawyers' model responses.

\section{METHODOLOGY}

The model of CLE at HKU appears to capture the essence of the aforementioned teachingservice pedagogy. It allows students to concomitantly acquire practical skills, theoretical knowledge, and a habit of service, through delivering legal assistance and street law

\footnotetext{
${ }^{59}$ McKeown (n.5), pp.28-36.

${ }^{60}$ Adewumi, A.A and Bamgbose, O.A. 'Attitude of Students to Clinical Legal Education: A Case Study of Faculty of Law, University of Ibadan' (2016) 3 Asian Journal of Legal Education 106, 111-115.

${ }^{61}$ Shanahan (n.3).

${ }^{62}$ Barnhizer (n.56).
} 
sessions to community partners and partaking in a self-reflective practice, while under the guidance of clinical faculty and pro bono lawyers. As such, how students view and experience CLE at HKU and whether their attitudes towards CLE change depending on clinic participation remains to be seen. To measure this empirically, the survey ${ }^{63}$, which largely replicated McKeown's survey ${ }^{64}$, was designed to elicit students' attitudes towards CLE, volunteering, and pro bono work. Specifically, the survey aimed to compare clinic and non-clinic student attitudes towards this tripartite of themes and identify any relationships present.

In the context of the survey, the terms CLE, volunteering, and pro bono work were each given a basic working definition, in order to ensure that respondents based their answers on a shared understanding, since it was conceivable that some respondents, particularly those in the lower years, might not have had any exposure to CLE, volunteering, or pro bono work at all. For these purposes, CLE was defined as "an experiential learning course where 'students are exposed to problems that lawyers might confront in practice'". ${ }^{65}$ Volunteering was defined as "any activity that involves spending time, unpaid, doing something that aims to benefit the environment or someone (individuals or groups) other

\footnotetext{
${ }^{63}$ See Appendix A.

${ }^{64}$ McKeown (n.6).

${ }^{65}$ Caplow (n.8).
} 
than, or in addition to, close relatives" ${ }^{66}$ Pro bono work was defined as "free, voluntary legal advice or representation provided by lawyers to individuals, charities, and community groups who cannot afford to pay for that advice or representation" ${ }^{67}$ Likert scales from "Strongly disagree" to "Strongly agree" with an "I am unfamiliar" option, tick boxes, and free text boxes were used to obtain attitudinal responses. This survey received ethical approval from the HKU Human Research Ethics Committee.

As one of two universities in Hong Kong that continued to implement CLE and with a comparatively larger law student population, HKU undergraduate law students were selected as the survey population. The survey was distributed in three compulsory law courses, with roughly the same number of students from discrete first- to fifth-year classes, to minimize non-response and selection biases and to ensure the sample size was an accurate and fair representation of the population. These courses were Law and Society with a total of 267 first-year students, Legal Research and Writing II with 254 second-year students, and Commercial Law with 288 third- to fifth-year students. The survey was administered at a ten-minute interval during the lectures, in which students were invited to complete the survey via a $Q R$ code or hyperlink. The format of an online

\footnotetext{
${ }^{66}$ 'Volunteering' $(\mathrm{NCVO})<\mathrm{https} / /$ www.ncvo.org.uk/policy-and-research/volunteering-policy $>$ accessed 25.03.2019.

67 'The Joint Pro Bono Protocol for Legal Work' (The Law Society)

$<$ https://www.lawsociety.org.uk/support-services/practice-management/pro-bono/the-pro-bonoprotocol/> accessed 25.03.2019.
} 
survey was selected, because it could be easily accessed from the student's computer during the lecture. Out of a total of 809 students surveyed, 125 responses were returned, which was a $15 \%$ response rate. Table 1 shows the demographic profile of the 125 respondents.

Table 1. Demographic characteristics of survey respondents

\begin{tabular}{llcc}
\hline Variable & Category & Frequency (n=125) & Percentage (\%) \\
\hline Gender & Male & 41 & $32.8 \%$ \\
& Female & 83 & $66.4 \%$ \\
& Prefer not to say & 1 & $0.8 \%$ \\
\hline Age & $<18$ years old & 1 & $0.8 \%$ \\
& $18-22$ years old & 118 & $94.4 \%$ \\
& $23-26$ years old & 5 & $4.0 \%$ \\
& Prefer not to say & 1 & $0.8 \%$ \\
\hline Year & 1 & 29 & $23.2 \%$ \\
& 2 & 49 & $39.2 \%$ \\
& 3 & 28 & $22.4 \%$ \\
& 4 & 15 & $12.0 \%$ \\
& 5 & 4 & $3.2 \%$ \\
\hline Degree program & Bachelor of Laws (LLB) & 51 & $40.8 \%$ \\
& Bachelor of Business Administration and Bachelor & 29 & $23.3 \%$ \\
& of Laws (BBA(Law)\&LLB)* & & \\
& Bachelor of Social Sciences (Government and Laws) & 30 & $24.0 \%$ \\
& and Bachelor of Laws (BSocSc(GL)\&LLB)* & & $12.0 \%$ \\
\hline & Bachelor of Arts and Bachelor of Laws (BA\&LLB)* & 15 & \\
\hline
\end{tabular}

* Integrated double degree course of 5 years' duration

Table 2 breaks down the demographic profile of the survey respondents by clinic participation, into clinic and non-clinic students respectively. 
Table 2. Demographic characteristics of survey respondents broken down by clinic participation

\begin{tabular}{|c|c|c|c|c|}
\hline Clinic participation & Variable & Category & Frequency & Percentage (\%) \\
\hline \multirow[t]{17}{*}{ Clinic students } & Total & & 12 & $100.0 \%$ \\
\hline & Gender & Male & 3 & $25.0 \%$ \\
\hline & & Female & 9 & $75.0 \%$ \\
\hline & & Prefer not to say & 0 & $0.0 \%$ \\
\hline & Age & $<18$ years old & 0 & $0 \%$ \\
\hline & & $18-22$ years old & 10 & $83.3 \%$ \\
\hline & & 23-26 years old & 2 & $16.7 \%$ \\
\hline & & Prefer not to say & 0 & $0.0 \%$ \\
\hline & Year & 1 & 0 & $0.0 \%$ \\
\hline & & 2 & 0 & $0.0 \%$ \\
\hline & & 3 & 6 & $50.0 \%$ \\
\hline & & 4 & 4 & $33.3 \%$ \\
\hline & & 5 & 2 & $16.7 \%$ \\
\hline & Degree program & LLB & 6 & $50.0 \%$ \\
\hline & & BBA(Law)\&LLB & 0 & $0.0 \%$ \\
\hline & & BSocSc(GL)\&LLB & 4 & $33.3 \%$ \\
\hline & & BA\&LLB & 2 & $16.7 \%$ \\
\hline \multirow[t]{17}{*}{ Non-clinic students } & Total & & 113 & $100.0 \%$ \\
\hline & Gender & Male & 38 & $33.6 \%$ \\
\hline & & Female & 74 & $65.5 \%$ \\
\hline & & Prefer not to say & 1 & $0.9 \%$ \\
\hline & Age & $<18$ years old & 1 & $0.9 \%$ \\
\hline & & $18-22$ years old & 108 & $95.6 \%$ \\
\hline & & 23-26 years old & 3 & $2.7 \%$ \\
\hline & & Prefer not to say & 1 & $0.9 \%$ \\
\hline & Year & 1 & 29 & $25.7 \%$ \\
\hline & & 2 & 49 & $43.4 \%$ \\
\hline & & 3 & 22 & $19.5 \%$ \\
\hline & & 4 & 11 & $9.7 \%$ \\
\hline & & 5 & 2 & $1.8 \%$ \\
\hline & Degree program & LLB & 45 & $39.8 \%$ \\
\hline & & BBA(Law)\&LLB & 29 & $25.7 \%$ \\
\hline & & BSocSc(GL)\&LLB & 26 & $23.0 \%$ \\
\hline & & BA\&LLB & 13 & $11.5 \%$ \\
\hline
\end{tabular}

Descriptive and inferential data analysis methods, including Pearson product-moment correlation coefficients and two-sample unequal variance (independent) t-tests, were 
used to analyze the quantitative data collected, in order to find relationships between the multiple variables of CLE, volunteering, and pro bono work. Data analysis was performed using STATA and Microsoft Excel. Qualitative responses regarding students' motivations for undertaking or intending to undertake clinics were categorized according to the cognitive, skills, and civic dimension framework and key themes were identified for analysis.

\section{DISCUSSION OF RESEARCH FINDINGS}

\section{Major Findings of the Study}

\section{Canvassing Students' Positive Attitudes Towards Clinical Legal Education}

The respondents had largely positive views towards CLE at HKU in terms of its educational value and its ability to encourage altruistic behavior after graduation. As shown in Figures 1 to 4, the majority selected "agree" or "strongly agree" on a Likert scale in response to statements relating to the civic dimension and service model of CLE, namely "Clinical work is important to support the wider community" (Figure 1), "Clinical work changes my perception of social and economic issues" (Figure 2), "Clinical work encourages me to engage in pro bono work after graduation" (Figure 3), and "Students who undertake clinical work are more likely to undertake pro bono work after

graduation" (Figure 4). This may suggest that clinic and non-clinic students alike are aware of the positive social impact that CLE has on the community in aiding access to 
justice and are optimistic that exposure to CLE will encourage a pro bono culture to develop, although it cannot be deduced why this is so. It is important to bear in mind that the respondents are a self-selecting group, so may tend to consist of students who are more aware of CLE to begin with.

One interesting observation to note is that there was a stronger positive response towards the blanket statement "Students who undertake clinical work are more likely to undertake pro bono work after graduation (emphasis added)" with $39.2 \%$ agreeing and $24.8 \%$ strongly agreeing with the statement, as compared to the self-directed statement "Clinical work encourages me to engage in pro bono work after graduation (emphasis added)" with $34.4 \%$ and $24 \%$ respectively. A likely explanation for this is that most respondents have not participated in CLE, and so are not as confident in CLE's ability to impact them personally, although they still agreed in the abstract on CLE's ability to encourage students as a whole to engage in pro bono work. Indeed, the majority of clinic students (7 out of 12) answered "strongly agree" to the statement "Clinical work encourages me to engage in pro bono work after graduation", which suggests that students with personal CLE experience are inclined to do pro bono work as a result of CLE, possibly due to the commitment to social justice instilled in them through the service model. 
Figure 1. The frequency of clinic and non-clinic students' responses on a Likert scale to the statement "Clinical work is important to support the wider community"

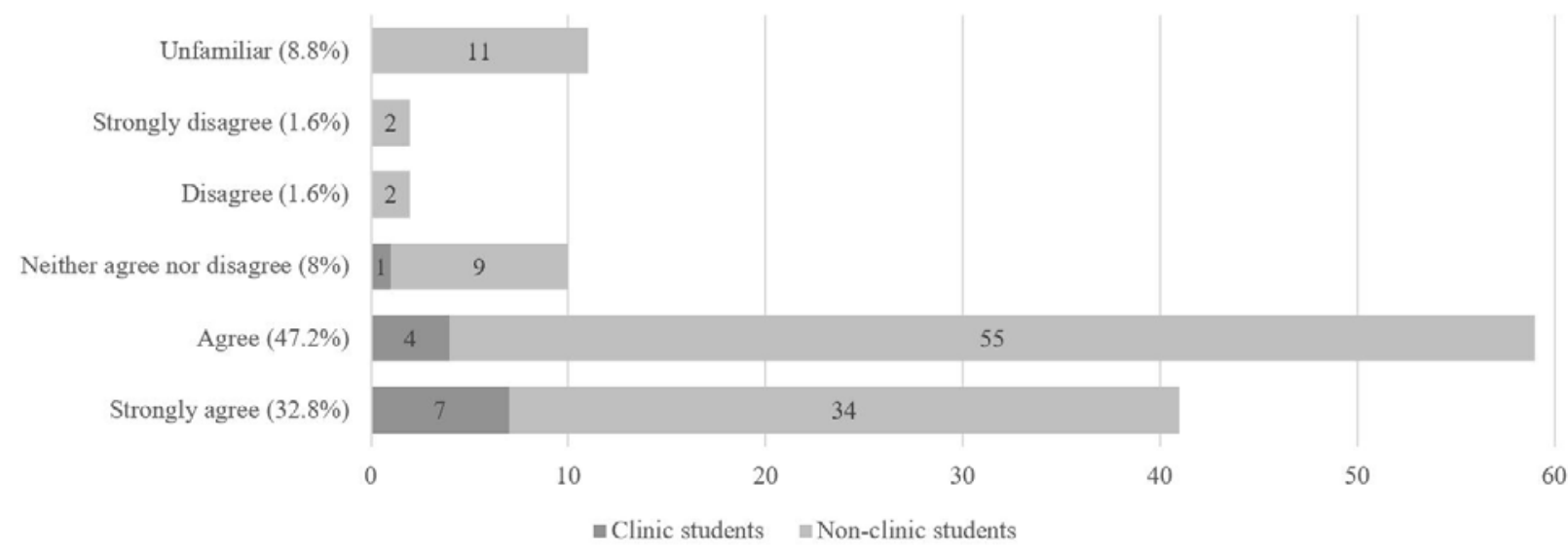

Figure 2. The frequency of clinic and non-clinic students' responses on a Likert scale to the statement "Clinical work changes my perception of social and economic issues"

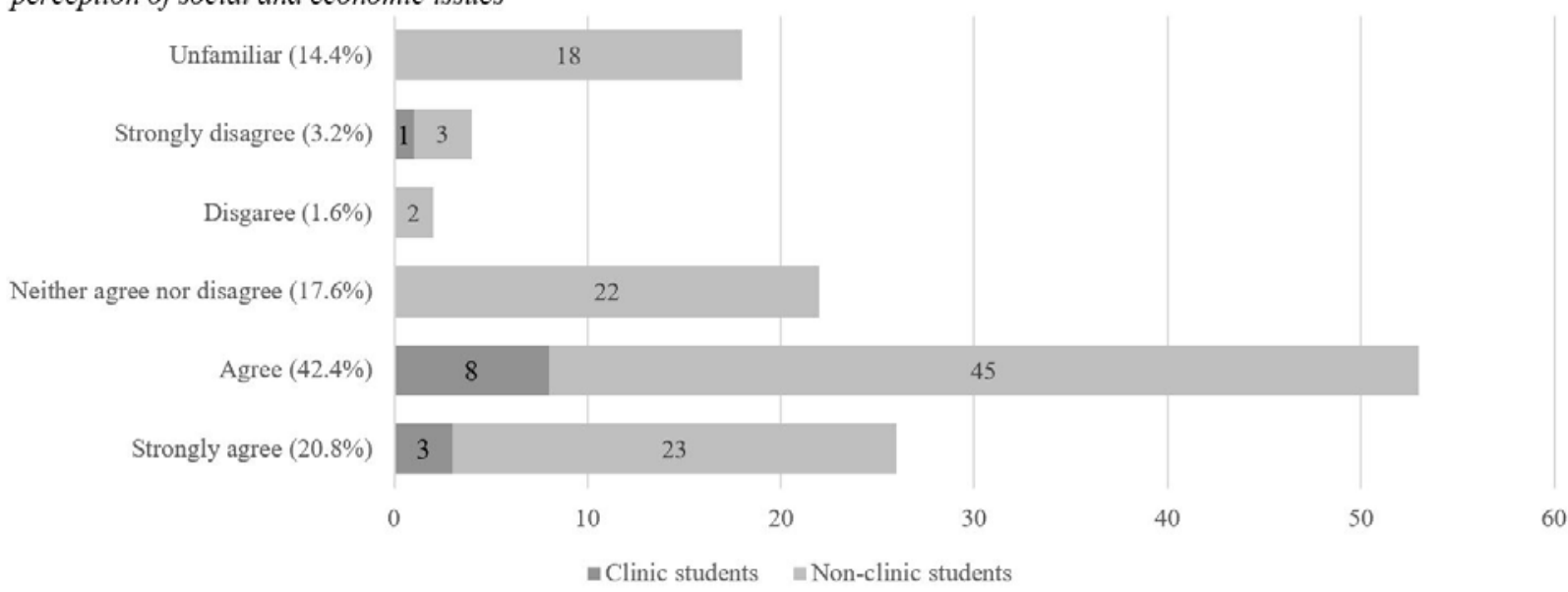

Figure 3. The frequency of clinic and non-clinic students' responses on a Likert scale to the statement "Clinical work encourages me to engage in pro bono work after graduation"

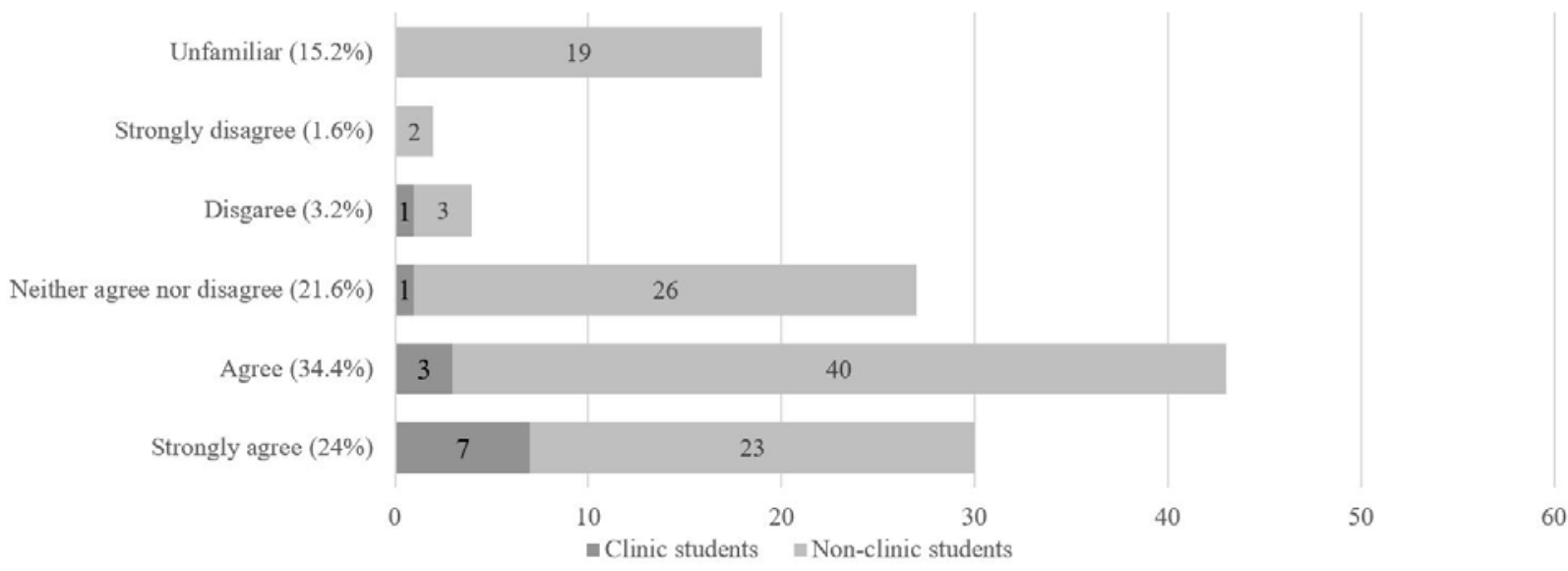


Figure 4. The frequency of clinic and non-clinic students' responses on a Likert scale to the statement "Students who undertake clinical work are more likely to undertake pro bono work after graduation"

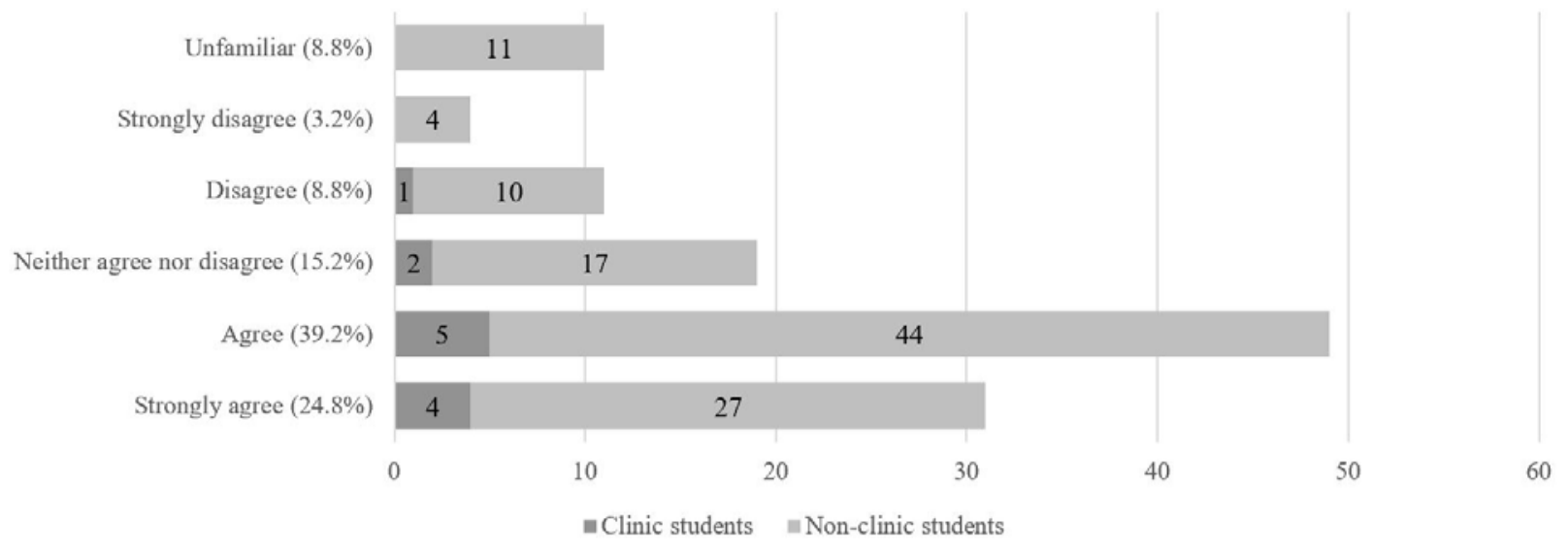

As for the cognitive dimension, the majority of respondents agreed or strongly agreed with the statement "Clinical work increases my awareness of social and economic issues" (Figure 5). This links to the civic dimension, so that ideally, the socio-economic knowledge students gain through CLE challenges their preconceived biases and changes perceptions. However, the majority responded "neither agree nor disagree" to the statement "Clinical work improves my academic performance" (Figure 6). One plausible explanation is that respondents interpreted "academic performance" narrowly to mean "grades", as opposed to the intended meaning of an improved ability to meet academic standards and the development of critical thinking processes. 
Figure 5. The frequency of clinic and non-clinic students' responses on a Likert scale to the statement "Clinical work increases my awareness of social and economic issues"

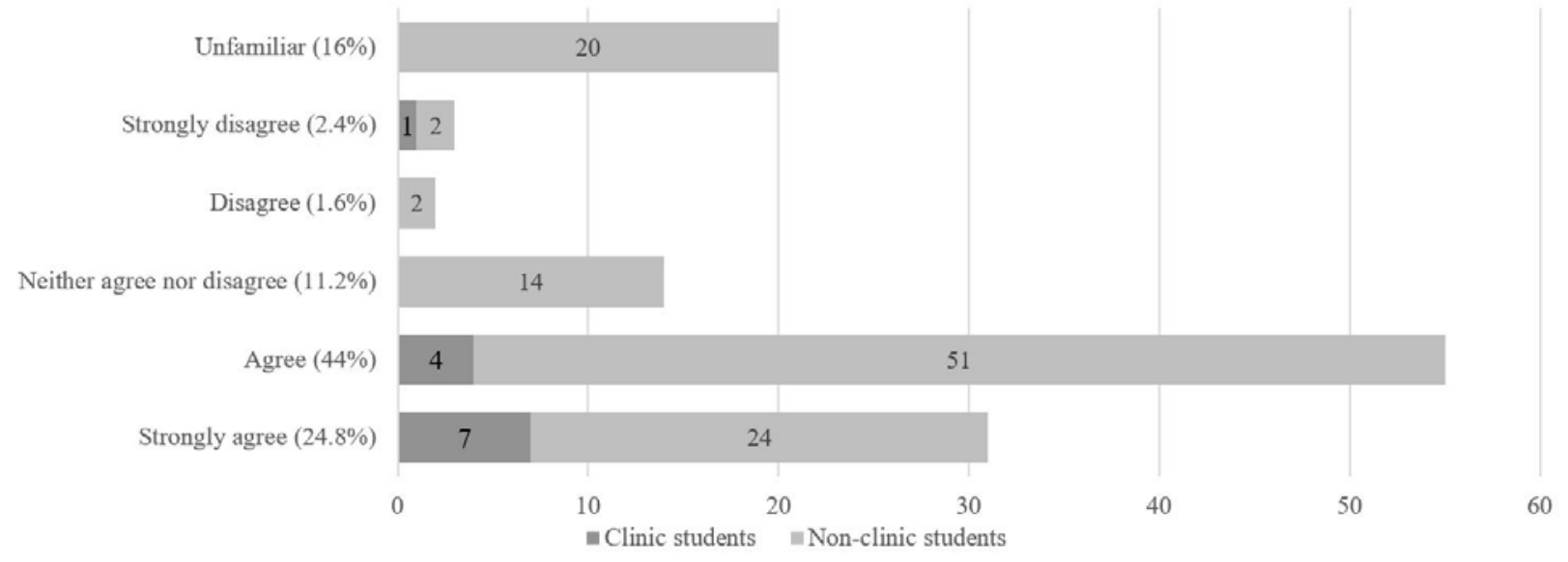

Figure 6. The frequency of clinic and non-clinic students' responses on a Likert scale to the statement "Clinical work improves my academic performance"
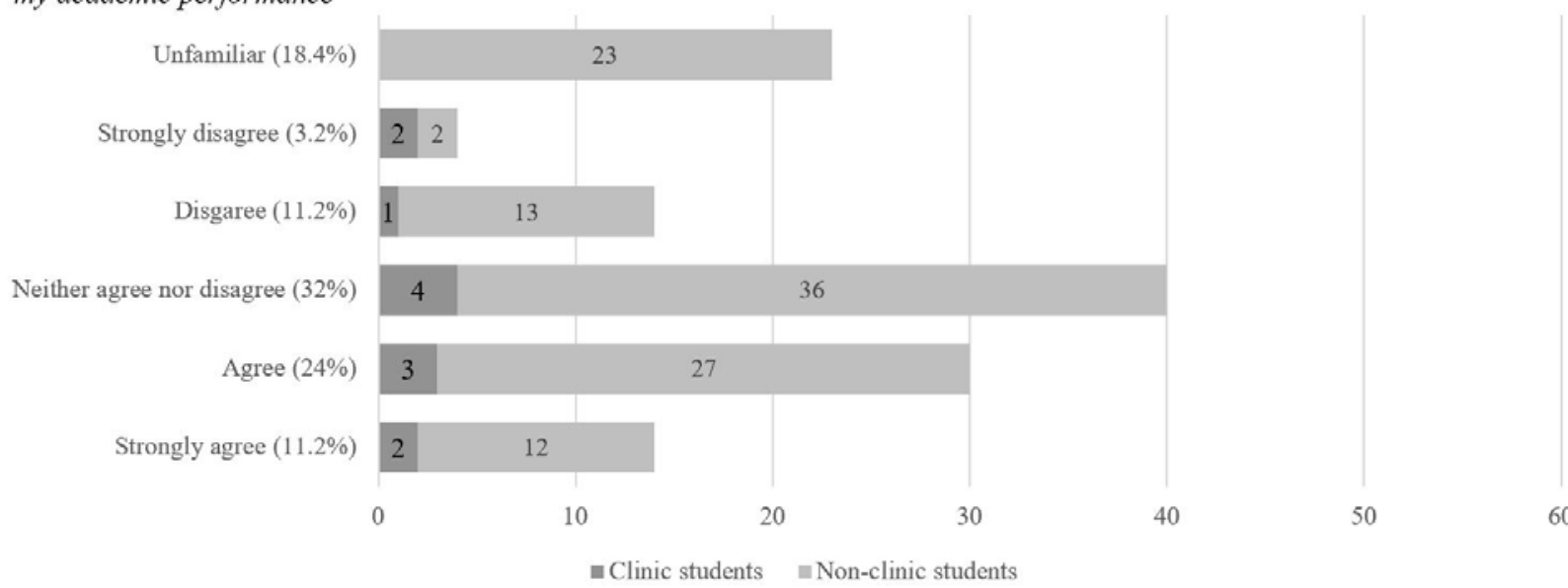

Regarding the skills dimension, the majority of respondents agreed or strongly agreed with the statement "Clinical work improves my legal skills" (Figure 7), which might suggest that both clinic and non-clinic students think CLE has the potential to constructively train their legal skills using its learning by doing teaching model. Relatedly, the majority also agreed with the statement "Clinical work assists me in obtaining employment" (Figure 8). One possible explanation is that students believe the 
practical legal skills and work experience gained through direct client interaction in CLE is valuable to employers, as it equips them to become more effective lawyers.

Figure 7. The frequency of clinic and non-clinic students' responses on a Likert scale to the statement "Clinical work improves my legal skills"

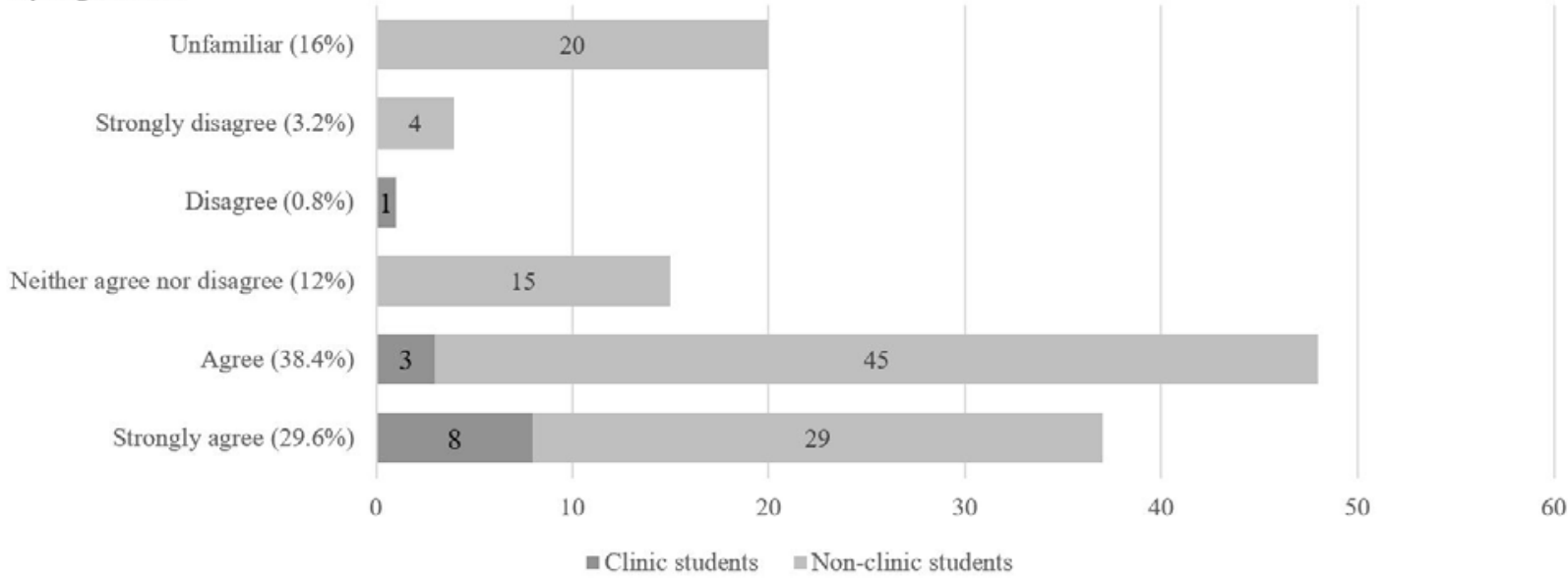

Figure 8. The frequency of clinic and non-clinic students' responses on a Likert scale to the statement "Clinical work assists me in obtaining employment"

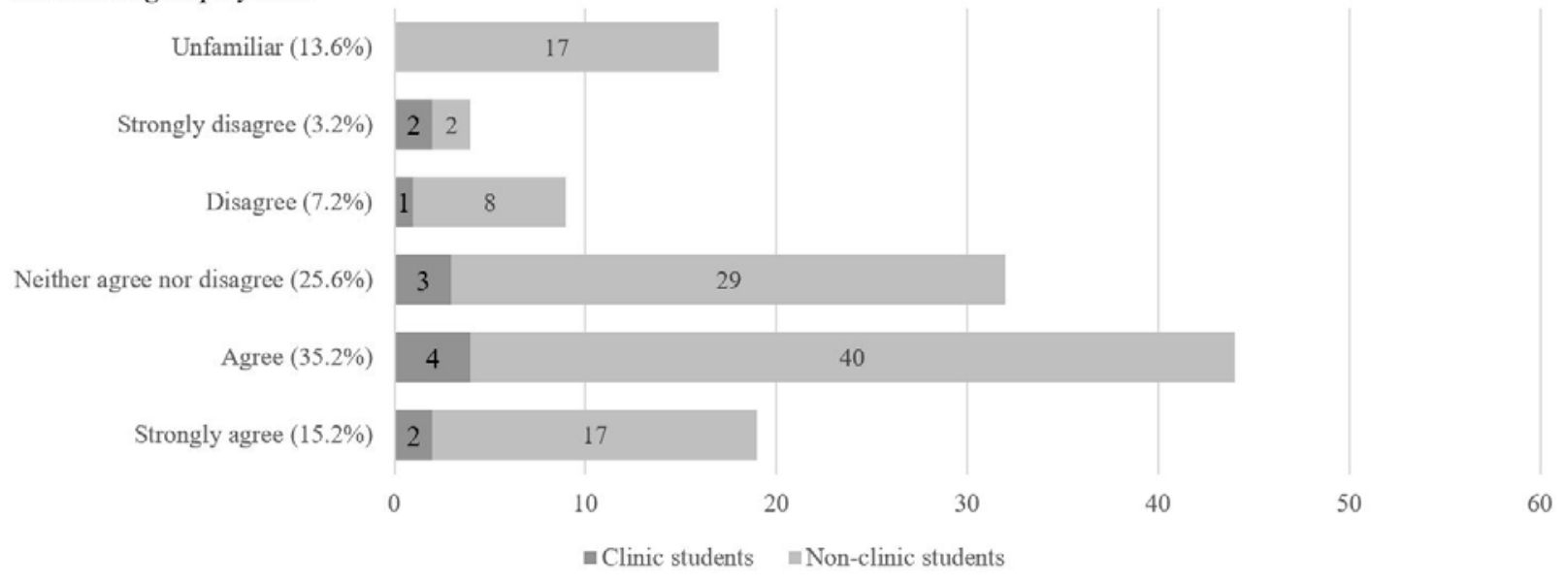

Despite their positive attitudes on CLE, the majority of respondents $(29.6 \%)$ answered "neither agree nor disagree" to the statement "Clinical work should be compulsory for all law students" (Figure 9). This may reflect that while the majority of students can see 
the advantages of CLE, they wish to retain their choice on whether or not to pursue CLE as an elective. One reason for this may be because the number of electives which students are allowed to take are already limited, and students might not want increased restrictions on their choice if a compulsory CLE course were to be introduced.

Figure 9. The frequency of clinic and non-clinic students' responses on a Likert scale to the statement "Clinical work should be compulsory for all law students"

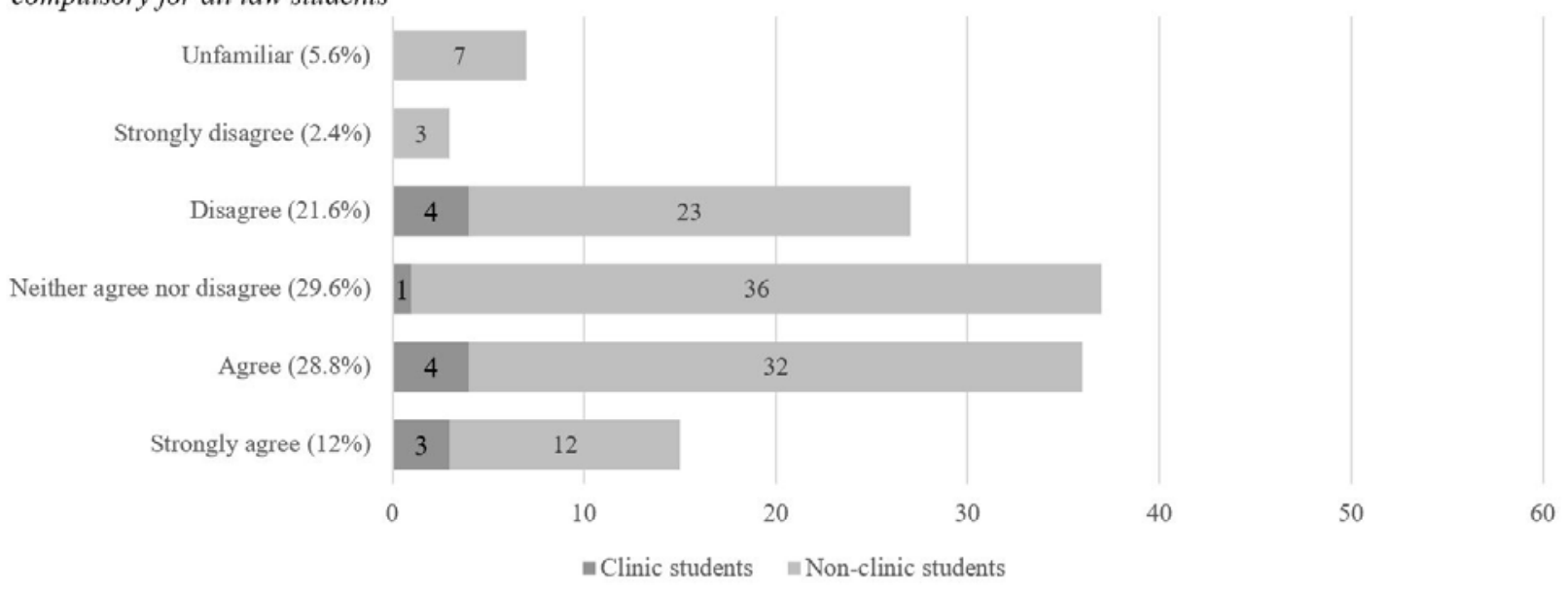

\section{Students' Motivations for Participating in Clinical Legal Education}

"Learning more", "getting practical experience", and "helping people" naturally emerged as key themes from the qualitative data analysis. Thus, students' motivations for undertaking CLE were conveniently grouped into three categories mirroring the cognitive, skills, and civic dimensions, noting any overlaps. While the majority of clinic student respondents (54.5\%) cited the civic dimension of CLE as their primary motivating factor for choosing to undertake CLE (Table 3), non-clinic students who intended to do 
CLE in the future (prospective clinic students) were slightly more drawn to the skills dimension (36\%) than the civic dimension (32\%) (Table 4).

This may be because clinic students who are currently undertaking or have already undertaken CLE are more strongly impressed by the civic dimension of their experience. Additionally, clinic students are exclusively Year 3 to 5 students who may already have gained work experience from internships and vacation schemes, making it a lesser priority in their minds, whereas most prospective clinic students are Year 1 and 2 students who may have had few, if any, chances to do internships, and thus are more keen to get practical experience through CLE. Interestingly, the cognitive dimension was the least compelling reason for both clinic and prospective clinic students to undertake CLE. This may suggest that students do not expect to learn black letter law in a clinical course, as the substantive material has largely been covered in core classes, and instead want to develop practical legal skills while helping the community.

Table 3. Clinic students' reasons for choosing to undertake a clinic

\begin{tabular}{|c|c|c|c|}
\hline Dimension & Frequency $(n=11)$ & Percentage (\%) & Responses of Clinic Students \\
\hline \multirow[t]{6}{*}{ Civic } & 6 & $54.5 \%$ & I love helping people \\
\hline & & & Wanted to help people \\
\hline & & & Use my legal knowledge to help lay clients \\
\hline & & & To serve the community \\
\hline & & & Good to contribute to the society \\
\hline & & & I thought it would be meaningful and rewarding \\
\hline \multirow[t]{2}{*}{ Civic and Skills } & 2 & $18.2 \%$ & Practical and meaningful \\
\hline & & & More practical experience, understand the legal needs of that particular group \\
\hline \multirow[t]{2}{*}{ Skills } & 2 & $18.2 \%$ & Get experience in client facing work \\
\hline & & & Interested in problem-solving \\
\hline Cognitive & 1 & $9.1 \%$ & To learn more about disability rights/human rights framework in Hong Kong \\
\hline
\end{tabular}


Table 4. Prospective clinic students' reasons for intending to undertake a clinic in the future

\begin{tabular}{|c|c|c|c|}
\hline Dimension & Frequency $(n=25)$ & Percentage (\%) & Responses of Prospective Clinic Students \\
\hline Civic & 8 & $32.0 \%$ & $\begin{array}{l}\text { Serve the community, promote access to justice } \\
\text { Make my free time more meaningful } \\
\text { Sounds fun and helping } \\
\text { It would be meaningful to help people in need } \\
\text { I believe equality and representation are worth fighting for and helping others for. } \\
\text { Underprotected group in HK, lack of exposure to area of law without taking this } \\
\text { It's meaningful and can give something back to the society } \\
\text { Covers issues I am interested in/ want to help out with }\end{array}$ \\
\hline Civic and skills & 2 & $8.0 \%$ & $\begin{array}{l}\text { To gain more experience and learn in a more hands-on method while still helping those in need. } \\
\text { To gain some hands-on/ practical experience, and to use my legal knowledge to help others }\end{array}$ \\
\hline Civic and cognitive & 2 & $8.0 \%$ & $\begin{array}{l}\text { It was very fun, allowed me to learn a lot of new things, actively participate in helping the } \\
\text { community and gaining wider exposure to real life issues at hand. } \\
\text { Because for me it is a good opportunity to leam from professors and legal practitioners. I am } \\
\text { always passionate about pro bono work. }\end{array}$ \\
\hline Skills & 9 & $36.0 \%$ & $\begin{array}{l}\text { To gain some experience in law } \\
\text { Gain some experience } \\
\text { Practical knowledge and experience } \\
\text { To gain experience } \\
\text { Gain exposure to legal career } \\
\text { Seems necessary to become a good practitioner } \\
\text { In-depth experience } \\
\text { It's a exposure and we can learn afterall } \\
\text { Soft skills }\end{array}$ \\
\hline Cognitive & 6 & $24.0 \%$ & $\begin{array}{l}\text { Expand my knowledge! } \\
\text { I have interest in development of the above areas } \\
\text { As a way to learm } \\
\text { Want to explore more }\end{array}$ \\
\hline
\end{tabular}

\section{Contrasting Clinic and Non-clinic Students' Attitudes}

Statistically significant differences $(p$-value $<0.05)$ were found between the attitudes of clinic and non-clinic students towards CLE (Figure 10). In essence, clinic students had significantly more positive views towards clinical work improving their legal skills $(p=$ $0.001)$, increasing their awareness $(p=0.012)$ and changing their perception $(p=0.043)$ of social and economic issues, encouraging them to engage in pro bono after graduation $(p$ $=0.002)$, and being important to support the wider community $(p=0.004)$. Clinic students were also significantly more agreeable towards doing pro bono work after graduation $(p$ $=0.007)$ and tended more to consider a firm's pro bono work when choosing their 
prospective employers $(p=0.028)$ (Figure 11). There were no significant differences in the attitudes of clinic and non-clinic students towards clinical work being compulsory for all law students, clinical work increasing students' likelihood to undertake pro bono work after graduation, clinical work assisting in obtaining employment, and clinical work improving academic performance.

Figure 10. T-tests comparing the means of clinic and non-clinic students' attitudes towards clinical legal education

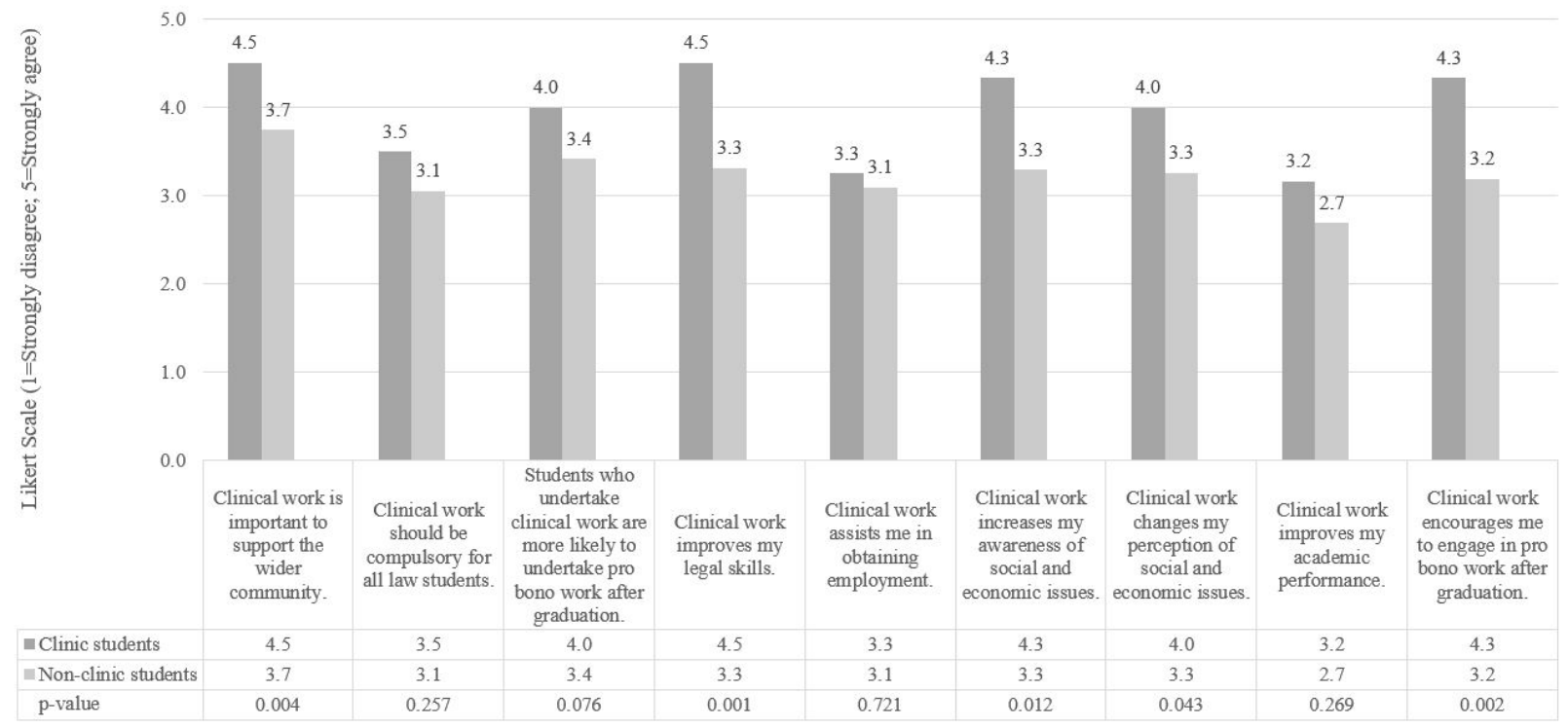


Figure 11. T-tests comparing the means of clinic and non-clinic students' attitudes towards pro bono work

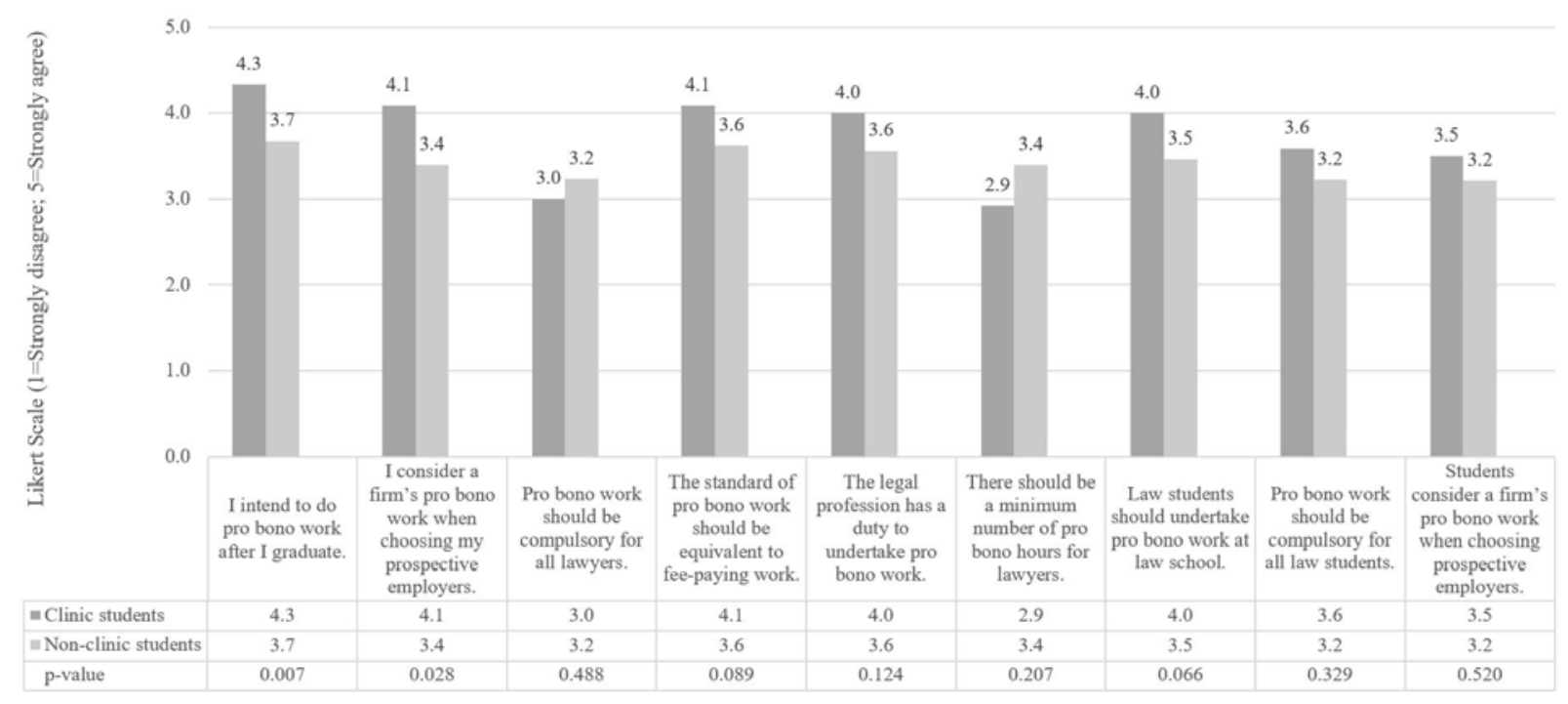

A likely explanation for this is that by virtue of enrolling in a CLE elective, of which one key objective is to provide legal assistance to a vulnerable client, clinic students inherently tend to be more interested in advancing social justice and doing pro bono work than their non-clinic peers. This is reflected in the primary motivation stated by clinic students for undertaking CLE, which is to help the community. Along the same lines, clinic students might be more likely to value the experiential learning methods of CLE in developing their legal skills and increasing or changing their understanding of socio-economic issues, otherwise they would opt for the traditional lecture-based public interest law or human rights electives. However, clinic students might not be significantly more agreeable than their non-clinic peers about CLE's ability to assist them in obtaining employment and 
improving academic performance, as these might not have been considerations compelling them to do CLE in the first place.

\section{Comparing Clinic Students' and Student Volunteers' Attitudes}

An intriguing comparison is drawn between clinic students' and student volunteers'

attitudes towards CLE (Table 5). Volunteering is a form of altruism which many law students (102 out of 125 respondents) engage in, so it is arguably interchangeable with

CLE. Consistently, there are stronger positive correlations between clinic participation and having positive attitudes towards clinics than volunteering participation. Clinic students' enthusiasm towards CLE may be linked to the choice to self-select as a clinic student, as reasoned above. Contrastingly, student volunteers who do not do CLE may be unfamiliar with CLE, thus have comparatively less positive views. 


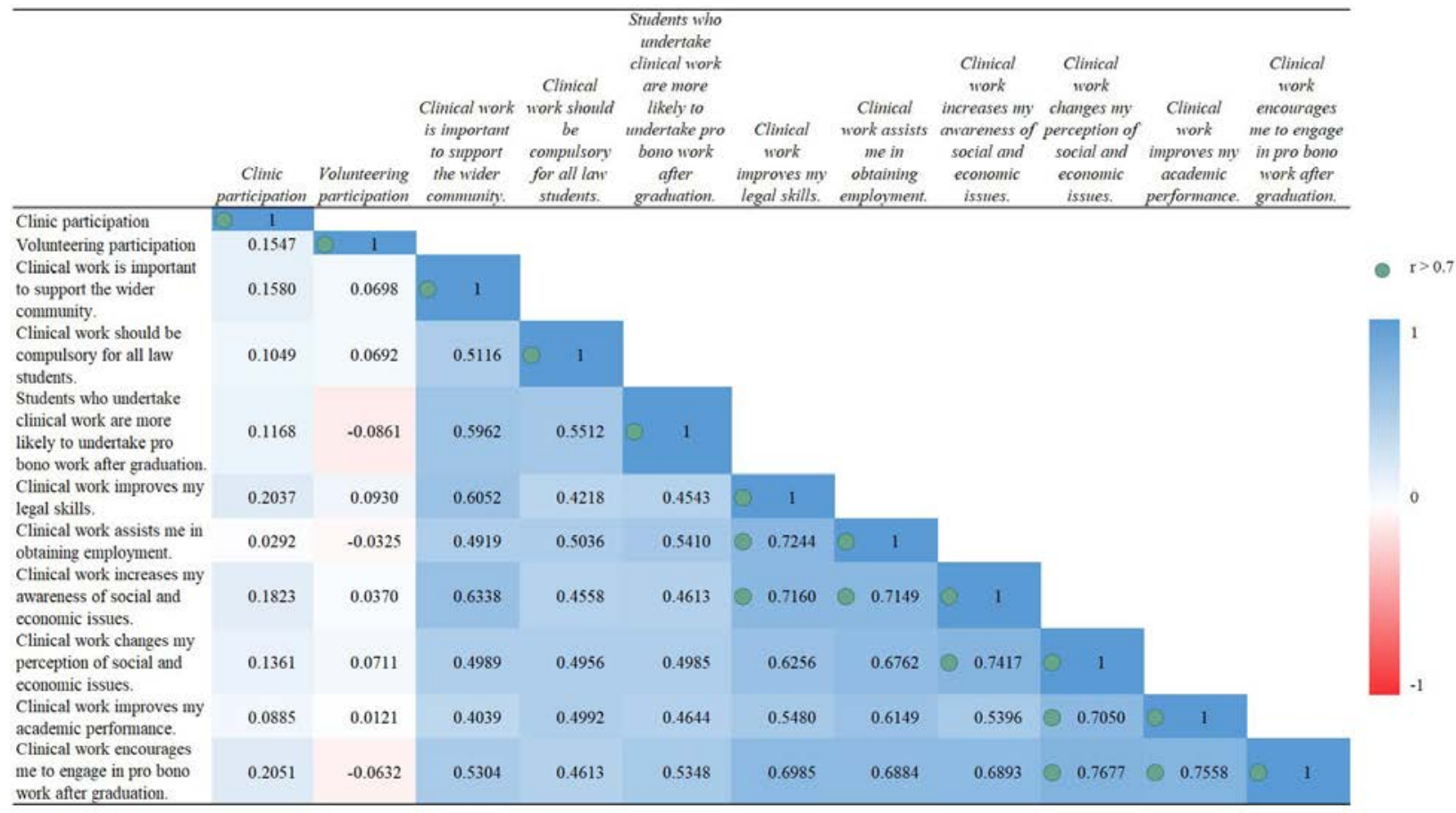

There is also a strong positive linear relationship $(r>0.7)$ between respondents who agreed that clinical work assisted them in obtaining employment and respondents who agreed that clinical work improved their legal skills and increased their awareness of socio-economic issues. This suggests respondents believe the improved skills and awareness gained from CLE will appear favorable in the eyes of potential employers.

Another interesting comparison is between clinic students' and student volunteers' attitudes towards pro bono work (Table 6). Although it could be argued that volunteering might also create a commitment to pro bono work after graduation, this does not appear to be the case, as there is a stronger positive relationship between clinic participation and 
having an intention to do pro bono work after graduation $(r=0.1688)$ than volunteering participation $(r=0.0882)$. This may be explained by the fact that most student volunteers engage in non-legal volunteering work $(\mathrm{n}=74 ; 72.5 \%)$, as opposed to legal $(\mathrm{n}=9 ; 8.8 \%)$ or both legal and non-legal volunteering work $(n=20 ; 19.6 \%)$, and therefore, they might not be exposed to legal problems and recognize the dire need for pro bono work through volunteering as a clinic student would through CLE.

Table 6. Correlation matrix of clinic participation, volunteering participation, and attitudes towards pro bono work

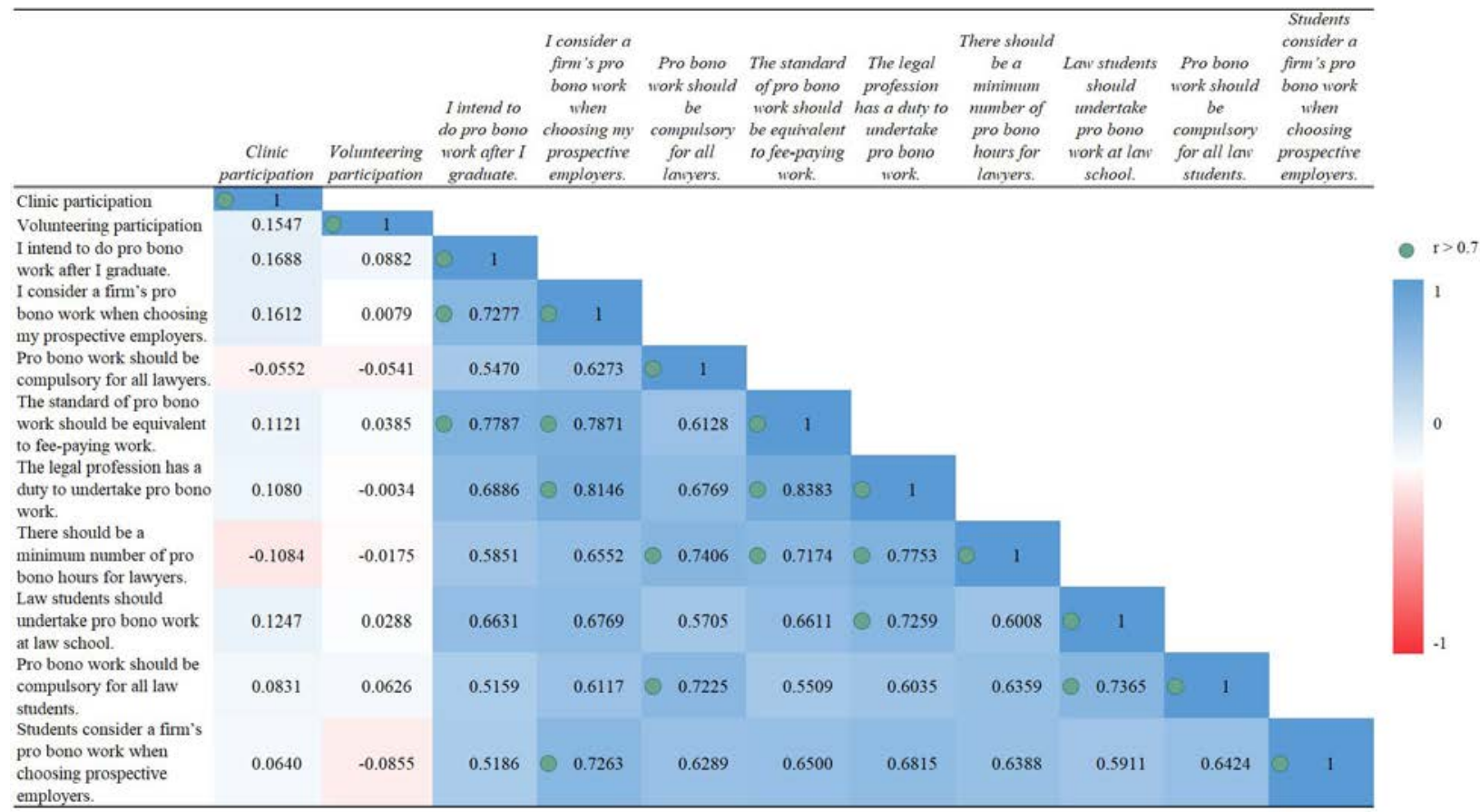

It may be worth noting that respondents who agreed that they considered a firm's pro bono work when choosing their prospective employer also tended to agreed that the legal profession had a duty to undertake pro bono work $(r=0.8146)$ and that the standard of 
pro bono work should be equivalent to fee-paying work $(r=0.7871)$. These were two of the strongest positive linear relationships present, which may indicate that students with a strong inclination towards pro bono work intended to act on such convictions by looking for law firms which emphasized their pro bono services. There was also a strong positive correlation between respondents who agreed that pro bono work should be compulsory for all lawyers and respondents who agreed that there should be a minimum number of pro bono hours for lawyers $(r=0.7406)$.

\section{Comparison with Previous Empirical Research}

The most cognate comparison with this study would be McKeown's work. ${ }^{68}$ The findings are consistent with McKeown's to the extent that respondents appreciated the skills development and enhanced employability aspects of CLE, which he coined as being "a personal benefit" ${ }^{69}$ However, unlike McKeown's study which found that there was only "marginally more appreciation of social and economic issues" as a result of CLE70, both clinic and non-clinic students at HKU are more evidently appreciative of CLE's ability to increase their understanding of socio-economic issues. As shown above, the majority of respondents agreed $(44 \%)$ or strongly agreed $(24.8 \%)$ with clinical work increasing their

\footnotetext{
${ }^{68}$ McKeown (n.6).

${ }^{69} \mathrm{Ibid},(2015) .$, pp.31.

${ }^{70} \mathrm{Ibid}$, (2015), pp.30.
} 
awareness and changing their perception of social and economic issues, and statistically significant differences were identified between clinic and non-clinic students views towards the same statements.

Furthermore, while McKeown's study found that "it is the personal benefits of [CLE] and pro bono work that students value more than any social benefit" ${ }^{\prime 1}$, this is only partially reflected by the survey data at HKU. HKU students agreed that CLE improves their legal skills and assists them in obtaining employment, which would fall within McKeown's interpretation of "personal benefit". However, HKU clinic students were largely motivated by altruistic reasons to undertake a clinic. Respondents stated that they chose to undertake CLE in order to "help people", "serve the community", and "contribute to society". Even prospective clinic students at HKU were only slightly more interested in the skills dimension (36\%) than the civic dimension (32\%), with respondents commenting that CLE was "meaningful" and that they wanted to "promote access to justice" and "give something back to society".

Finally, although McKeown's study concluded that "respondents, whether having carried out [CLE] or not at law school, were neutral...as to whether they would carry out

\footnotetext{
${ }^{71}$ Ibid, (2015), pp.34.
} 
pro bono work following graduation"72, both clinic and non-clinic students at HKU agreed or strongly agreed with the statement that clinical work encourages them personally and students as a whole to undertake pro bono work after graduation. The difference between clinic and non-clinic students on the statement "Clinical work encourages me to engage in pro bono work after graduation" was statistically significant. Although causation cannot be inferred, as the data only captures students' attitudes at one instance in time, the data suggests that clinic students are significantly more agreeable towards doing pro bono work and so are distinct in this aspect from their peers.

\section{Theoretical and Practical Implications}

The respondents' attitudes aligned with the theoretical framework above, which implies clinic and non-clinic students alike believed that HKU has effectively put into practice the CLE teaching-service pedagogy. The practical implications for HKU law students are that, although each student's experience of CLE is inevitably unique, students are generally satisfied that CLE achieves certain pedagogical aims. In terms of the teaching model, most respondents, and especially clinic students, agreed with statements to the effect that CLE led to personal development in the cognitive, skills, and civic dimensions. Similarly, under the service model, the majority, and especially clinic students, agreed

\footnotetext{
${ }^{72}$ Ibid, (2015).
} 
with the statement that CLE encouraged their participation in pro bono work after graduation. These may be persuasive factors for prospective clinic students in deciding whether or not to take a CLE elective, and so may be of interest to upper-year law students.

For clinical faculty, the practical implications of this study may depend on what they aim to achieve through their clinics. If, for example, clinical faculty aspire to generate longterm, sustainable pro bono participation as a result of CLE, the survey data is inconclusive as to whether this has been achieved. While students largely agree that clinical work encourages them to engage in pro bono work after graduation, the correlation analysis reveals only a weak positive correlation $(r=0.1688)$ between respondents' clinic participation and intention to do pro bono work after graduation. Whether the respondents' intentions to do pro bono work will translate into any concrete actions, for instance, by taking up pro bono assignments during their professional practice, is another matter entirely and may be gauged by surveying former clinic students who are now practitioners. ${ }^{73}$ Nonetheless, the survey results indicate that CLE is an encouraging first step in the path to alleviating Hong Kong's public interest law deficit, as it exposes clinic

\footnotetext{
${ }^{73}$ Skrodzka, M., Chia, J. \& Bruce-Jones, E. 'The Next Step Forward - The Development of Clinical Legal Education in Poland through a Clinical Pilot Program in Bialystok' (2008) 2 Columbia Journal of East European Law 56, 84.
} 
students to pro bono work at an early stage of their legal careers and may in the least encourage students to set the intention to engage in pro bono work after graduation.

This study may yield practical implications for law firms. It suggests that students are increasingly aware of and interested in their prospective firms' pro bono work. Recruiters that want to attract students who intend to do pro bono work after graduation may consider capitalizing on the pro bono work that their firm has done to meet their corporate social responsibility duties and emphasizing their belief that the standard of pro bono work should be equivalent to fee-paying work. Recruiters may also refer to clinic students' CLE experience as an impactful learning experience, which generally speaking might have improved their legal skills and increased their awareness and changed their perception of social and economic issues, as well as potentially being an indication of their intention to do pro bono work at their firm.

\section{Limitations of the Study}

One limitation of this study is the short time frame in which the study was done. The short time frame affects the validity of the data, because the responses can only provide a snapshot of student attitudes at a specific point in time. Therefore, the data collected does not take into account the fact that students' answers to the same questions may change over time as they are exposed to different viewpoints. Only correlation can be 
established from the data, since correlation does not imply causation, as opposed to a longitudinal study where causation may be deduced. Within the survey, most questions asked only for a response on a Likert scale, in order to maintain its simplicity and accessibility to the target population. This meant that the reasons for the students' responses could not be identified concretely, and at most could only be given possible interpretations based on CLE theories.

A further limitation is the response rate of $15 \%$. Applying the "liberal conditions" (10\% sampling error, $80 \%$ confidence level) to a class of around 750 to 1,000 students, the response rate of $15 \%$ would easily satisfy the required response rate of $3 \% .{ }^{74}$ To this end, the responses would be a representative sample of student attitudes as a whole. However, the "stringent conditions" ( $3 \%$ sampling error; 95\% confidence level) would require a response rate of $48 \%$, which is much higher than what was achieved.

A final limitation is that the study relates only to the target survey population of first- to fifth-year HKU undergraduate law students. The claims made cannot and do not attempt to be generalized to apply to other students or universities, since each university has its own individual approach towards CLE. It is also difficult to generalize the results across

\footnotetext{
${ }^{74}$ Nulty, D.D. 'The adequacy of response rates to online and paper surveys: what can be done?' (2008) 33 Assessment \& Evaluation in Higher Education 301, 310.
} 
all HKU law students in the various programs, as every cohort may have divergent views and experiences towards CLE.

\section{Recommendations and Directions for Further Study}

It is recommended that a longitudinal survey could be administered to students at a minimum of two intervals at the beginning and end of the semester, which would mitigate against the problems of having a short time frame and would determine whether

CLE had potentially caused any attitudinal changes for clinic students. Focus groups could also be introduced in order to better understand the reasons behind the respondent's answers. Alternatively, free text boxes could be used within the survey to illicit justifications for answers to questions of particular interest, but this may not be preferred as it could lead to increased survey fatigue and decreased response rates.

This study could be extended to CUHK which also runs CLE courses, so as to gain a complete understanding of the effects of CLE in Hong Kong following the RedmondRoper Report. A comparative study could be conducted to compare whether the impact of CLE is different in CUHK, and if so, how and why it is different from HKU. The study could also test whether there is a need or the capacity to implement Caplow's suggestion of a joint clinic and consider other possible methods of cooperation. 
Another direction for extension would be to investigate the impact of a particular format of CLE, for instance, whether CLE has the same impact in the format of street law as opposed to a live-client clinic. The role of different stakeholders could also be considered. For example, whilst this survey focused solely on students' attitudes towards CLE, an interesting question could be whether CLE improves access to justice for the target communities and improves their understanding of the law. Another extension could be to survey clinical faculty to depict the challenges and successes of CLE from their point of view..$^{75}$ The data collected with regards to volunteering and pro bono work could also be analyzed closely and be used to inform further research on law students' altruistic inclinations beyond CLE.

\section{CONCLUSION}

To mark ten years of CLE at HKU, the study shows that CLE has been a fruitful pursuit. Both clinic and non-clinic students think that CLE improves legal skills, enhances employability, increases their awareness and changes their perception of socio-economic issues, encourages participation in pro bono work after graduation, and is important to support the wider community. The qualitative responses indicate that CLE gives students the meaningful opportunity to serve the community, while also developing practical

\footnotetext{
${ }^{75}$ Skrodzka, Chia, and Bruce-Jones (n.73).
} 
legal skills. From the students' perspective, the teaching-service model has been successfully integrated at HKU, realizing the vision of the Redmond-Roper Report and Caplow's vision from more than a decade ago.

It remains to be seen how CLE will continue to develop in the years to come as universities place greater emphasis on experiential learning and whether CLE will manifest itself in any positive impacts on the development of a rich pro bono culture in the legal community in Hong Kong. It is hoped that CLE will continue to serve as a vehicle to strengthen existing partnerships between law students, pro bono lawyers, and community groups, in order to grow a culture of service which seeks to empower members of the community and support both their legal and non-legal movements for change. As clinic students progress through their careers and take on leadership roles in various sectors of Hong Kong society, there is enormous potential for the socio-economic awareness and community-driven mindset gained through CLE to influence their decision-making and play a role in ameliorating injustices. 


\section{Appendix A: Survey}

\section{Clinical legal education, volunteering, and pro bono work}

We invite you to participate in a research study: "HKU law student attitudes towards clinical legal education, volunteering, and pro bono work".

The purpose of the study is to better understand HKU student attitudes towards clinical legal education, volunteering, and pro bono work.

The online survey (below) will only take you about 7 minutes to complete. Your participation is completely voluntary. You can choose not to answer any of the questions, and you can choose to terminate the survey at any time without negative consequences. All information collected will remain strictly confidential. Individual details will not be disclosed or identifiable from this survey.

If you have any questions about the research, please feel free to contact principal investigator

or student investigator

If you have questions about your rights as a research participant, please contact the Human Research Ethics Committee, HKU (2241-5267).

* Required

1. I understand the procedures described above and agree to participate in this study. * Mark only one oval.

I agree

\section{Basic information}

2. Please state your intended career aspirations before you entered law school. *

Mark only one oval.

\section{Lawyer}

Non-lawyer

3. If you answered "lawyer" to Q.1, what was your intended area of practice? (Tick all that apply): Check all that apply.
Private corporate/commercial solicitor
Private criminal solicitor
Government lawyer
Barrister
In-house counsel
Human rights lawyer
Other: 
4. Have your career aspirations changed? *

Mark only one oval.

Yes

No

5. If you answered "yes" to Q.3, why did your intended career aspirations change?

6. If you answered "yes" to Q.3, please state your current career aspirations.

Mark only one oval.

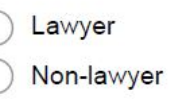

7. If you answered "lawyer" to Q.5, what is your intended area of practice? (Tick all that apply): Check all that apply.

Private corporate/commercial solicitor

Private criminal solicitor

Government lawyer

Barrister

In-house counsel

Human rights lawyer

Other:

8. How do you identify your gender? (Please tick one or more boxes.) * Check all that apply.
Male
Female
Prefer not to say
Other: 
9. How old are you? *

Mark only one oval.

Under 18 years old

18-22 years old

23-26 years old

27-38 years old

39 or older

Prefer not to say

10. What is your program of study? *

Mark only one oval.
LLB
BBA(Law)\&LLB
BSS (G\&L)\&LLB
BA\&LLB
Exchange
Other:

11. Which year are you in? *

Mark only one oval.
Year 1
Year 2
Year 3
Year 4
Year 5
Other:

12. Which secondary school curriculum did you study?

Mark only one oval.

DSE

IB Diploma

A-levels

Other:

\section{Clinical legal education}

A clinic is an experiential learning course where "students are exposed to problems that lawyers might confront in practice" (Caplow, 2006). Activities undertaken in a clinic may include: Collaborating with NGOs on projects, designing and implementing interactive legal teaching curricula, advising unrepresented individuals or groups, etc. A clinic does NOT include internships, vacation schemes, or other work experience. 
13. Have you undertaken, or are you currently undertaking, any clinic(s) at HKU? * Mark only one oval.

$$
\begin{aligned}
& \text { Yes } \\
& \text { No }
\end{aligned}
$$

14. If you answered "yes" to Q.12, please state which clinic(s).

15. If you answered "yes" to Q.12, please state why you chose to undertake the clinic(s).

16. Do you intend to take any clinics in the future? * Mark only one oval.

$$
\begin{aligned}
& \text { Yes } \\
& \text { No }
\end{aligned}
$$

17. If you answered "yes" to Q.15, please state which clinic(s).

18. If you answered "yes" to Q.15, please state why you intend to undertake the clinic(s). 
19. Please state whether you agree or disagree with the following statements. * Mark only one oval per row.

\begin{tabular}{|c|c|c|c|c|c|c|}
\hline & $\begin{array}{l}\text { Strongly } \\
\text { disagree }\end{array}$ & Disagree & $\begin{array}{c}\text { Neither agree } \\
\text { nor disagree }\end{array}$ & Agree & $\begin{array}{l}\text { Strongly } \\
\text { agree }\end{array}$ & $\begin{array}{l}\text { I am } \\
\text { unfamiliar with } \\
\text { clinical work }\end{array}$ \\
\hline $\begin{array}{l}\text { Clinical work is } \\
\text { important to support } \\
\text { the wider community. }\end{array}$ & & & & & & \\
\hline $\begin{array}{l}\text { Clinical work should } \\
\text { be compulsory for all } \\
\text { law students. }\end{array}$ & & & & & & \\
\hline $\begin{array}{l}\text { Students who } \\
\text { undertake clinical } \\
\text { work are more likely } \\
\text { to undertake pro } \\
\text { bono work after } \\
\text { graduation. }\end{array}$ & & & & & & \\
\hline $\begin{array}{l}\text { Clinical work } \\
\text { improves my legal } \\
\text { skills }\end{array}$ & & & & & & \\
\hline $\begin{array}{l}\text { Clinical work assists } \\
\text { me in obtaining } \\
\text { employment. }\end{array}$ & & & & & & \\
\hline $\begin{array}{l}\text { Clinical work } \\
\text { increases my } \\
\text { awareness of social } \\
\text { and economic } \\
\text { issues. }\end{array}$ & & & & & & \\
\hline $\begin{array}{l}\text { Clinical work } \\
\text { changes my } \\
\text { perception of social } \\
\text { and economic } \\
\text { issues. }\end{array}$ & & & & & & \\
\hline $\begin{array}{l}\text { Clinical work } \\
\text { improves my } \\
\text { academic } \\
\text { performance. }\end{array}$ & & & & & & \\
\hline $\begin{array}{l}\text { Clinical work } \\
\text { encourages me to } \\
\text { engage in pro bono } \\
\text { work after } \\
\text { graduation. }\end{array}$ & & & & & & \\
\hline
\end{tabular}


20. Complete the following sentence (Tick all that apply): A lawyer's role should be... * Check all that apply.

To be committed to creating a just, fair, and moral society

To solve the client's legal problems

To work collaboratively with lawyers to understand the client's legal problems

To empower the client to pursue their legal rights independently of a lawyer

To make choices for the client

To enhance the skills and knowledge base of the client

To solve the client's non-legal problems or problems unable to be redressed by the law

To work collaboratively with lawyers and non-lawyers to understand the client's social and economic problems

To educate the client about their choices and leave the client autonomous to decide which choice to make

Other:

21. Have you undertaken, or are you currently undertaking, any of the courses listed below? (Tick all that apply):

Check all that apply.

Social justice summer internship (LLAW2011)

Clinical legal education programme - general stream (LLAW3148)

Clinical legal education programme - refugee stream (LLAW3210)

Human rights in practice (LLAW3222)

Disability rights clinic (LLAW3246)

Ethical lawyering for public interest (LLAW3247)

The global migration legal clinic (LLAW3252)

\section{Volunteering}

Volunteering is "any activity that involves spending time, unpaid, doing something that aims to benefit the environment or someone (individuals or groups) other than, or in addition to, close relatives" (The National Council for Voluntary Organisations, 2019).

22. Outside your program of study, do you undertake or have you previously undertaken any volunteering? *

Mark only one oval.

Yes

No

23. If you answered "yes" to Q.21, what type of volunteering do you undertake? Mark only one oval.
Legal
Non-legal
Both
Other: 
24. If you answered "yes" to Q.21, please state why you undertake volunteering.

25. Please state whether you agree or disagree with the following statements. * Mark only one oval per row.

\begin{tabular}{|c|c|c|c|c|c|c|}
\hline & $\begin{array}{l}\text { Strongly } \\
\text { disagree }\end{array}$ & Disagree & $\begin{array}{c}\text { Neither agree } \\
\text { nor disagree }\end{array}$ & Agree & $\begin{array}{l}\text { Strongly } \\
\text { agree }\end{array}$ & $\begin{array}{l}\text { I am } \\
\text { unfamiliar with } \\
\text { volunteering }\end{array}$ \\
\hline $\begin{array}{l}\text { Students who } \\
\text { undertake } \\
\text { volunteering are } \\
\text { more likely to } \\
\text { undertake pro bono } \\
\text { work after } \\
\text { graduation. }\end{array}$ & & & & & & \\
\hline $\begin{array}{l}\text { I am likely to } \\
\text { volunteer after I } \\
\text { graduate. }\end{array}$ & & & & & & \\
\hline $\begin{array}{l}\text { Volunteering is } \\
\text { important to support } \\
\text { the wider community. }\end{array}$ & & & & & & \\
\hline $\begin{array}{l}\text { Volunteering } \\
\text { improves my legal } \\
\text { skills. }\end{array}$ & & & & & & \\
\hline $\begin{array}{l}\text { Volunteering assists } \\
\text { me in obtaining } \\
\text { employment. }\end{array}$ & & & & & & \\
\hline $\begin{array}{l}\text { Volunteering } \\
\text { increases my } \\
\text { awareness of social } \\
\text { and economic } \\
\text { issues. }\end{array}$ & & & & & & \\
\hline $\begin{array}{l}\text { Volunteering } \\
\text { changes my } \\
\text { perception of social } \\
\text { and economic } \\
\text { issues. }\end{array}$ & & & & & & \\
\hline $\begin{array}{l}\text { Volunteering } \\
\text { encourages me to } \\
\text { engage in pro bono } \\
\text { work after } \\
\text { graduation. }\end{array}$ & & & & & & \\
\hline
\end{tabular}

\section{Pro bono work}

Pro bono work is free, voluntary legal advice or representation provided by lawyers to individuals, charities, and community groups who cannot afford to pay for that advice or representation (Law Society UK, 2019). 
26. Please state whether you agree or disagree with the following statements. * Mark only one oval per row.

\begin{tabular}{|c|c|c|c|c|c|c|}
\hline & $\begin{array}{l}\text { Strongly } \\
\text { disagree }\end{array}$ & Disagree & $\begin{array}{c}\text { Neither agree } \\
\text { nor disagree }\end{array}$ & Agree & $\begin{array}{c}\text { Strongly } \\
\text { agree }\end{array}$ & $\begin{array}{c}\text { I am unfamiliar } \\
\text { with pro bono } \\
\text { work }\end{array}$ \\
\hline $\begin{array}{l}\text { I intend to do pro } \\
\text { bono work after I } \\
\text { graduate. }\end{array}$ & & & & & & \\
\hline $\begin{array}{l}\text { I consider a firm's } \\
\text { pro bono work when } \\
\text { choosing my } \\
\text { prospective } \\
\text { employers. }\end{array}$ & & & & & & \\
\hline $\begin{array}{l}\text { Pro bono work } \\
\text { should be } \\
\text { compulsory for all } \\
\text { lawyers. }\end{array}$ & & & & & & \\
\hline $\begin{array}{l}\text { The standard of pro } \\
\text { bono work should be } \\
\text { equivalent to fee- } \\
\text { paying work. }\end{array}$ & & & & & & \\
\hline $\begin{array}{l}\text { The legal profession } \\
\text { has a duty to } \\
\text { undertake pro bono } \\
\text { work. }\end{array}$ & & & & & & \\
\hline $\begin{array}{l}\text { There should be a } \\
\text { minimum number of } \\
\text { pro bono hours for } \\
\text { lawyers. }\end{array}$ & & & & & & \\
\hline $\begin{array}{l}\text { Law students should } \\
\text { undertake pro bono } \\
\text { work at law school. }\end{array}$ & & & & & & \\
\hline $\begin{array}{l}\text { Pro bono work } \\
\text { should be } \\
\text { compulsory for all } \\
\text { law students. }\end{array}$ & & & & & & \\
\hline $\begin{array}{l}\text { Students consider a } \\
\text { firm's pro bono work } \\
\text { when choosing } \\
\text { prospective } \\
\text { employers. }\end{array}$ & & & & & & \\
\hline
\end{tabular}

27. Have you been or are you currently part of a student-run group? * Mark only one oval.

$$
\begin{aligned}
& \text { Yes } \\
& \text { No }
\end{aligned}
$$

28. If you answered "yes" to Q.26, please state which group (or groups) and your role within the group. 


\section{Thank you for your response.}

Thank you for completing this survey. Please note that by clicking the 'submit' button, you consent to the data that you have provided being used by the University of Hong Kong in accordance with the information on the first page of this survey.

Powered by

Google Forms 